\title{
MUSICAL ENCOUNTER IN JAVA AND BALI*
}

\author{
Ward Keeler
}

When Claude Lévi-Strauss speaks, in the "Overture" to The Raw and the cooked, of music as "the supreme mystery of the science of man," l he refers to a language that can be communicated beyond the boundaries of, yet still within, culture. Inscribing a very small arc within that universal circle, I would like to consider two musical ensembles, Javanese and Balinese gamelan, whose cultural contexts as well as musics have marked sympathies. In each case, the line of my argument wends a rather long way from conventions of speech to social interaction to percussion sounds. Hopefully the pengècèt, as the Balinese call the fast, heavy-stressed final section of a musical piece, will warrant the long development.

\section{Java $^{2}$}

Javanese society often strikes Westerners as formless or, to use Clifford Geertz's word, "vague," because on a personal level it seems mindless, and, on a corporate level, inoperative. But the very "formality" which Westerners consider empty provides Javanese society with form, precisely, and fits into a system of interaction that is, in its own way, both elastic and binding. I would like to describe Javanese interaction first as a system--the contrasting types of behavior which Javanese define as alus and kasar. As the distinction appears most clearly in language, I begin from there. Then, I will try to point out what rules apply to all Javanese interaction, rules which, while open to variation, nevertheless run deeper than any one type of behavior:

* This article is based on the final report I submitted to the Lembaga Ilmu Pengetahuan Indonesia in May 1974. I would like to thank the members of that institute for making possible my stay in Indonesia. I would also like to thank my gamelan teacher, Bapak Sastrapustaka, of Panembahan, Yogyakarta; Mas Amin Yitno, a student of anthropology at Universitas Gajah Mada; I Nengah Wirasa, of Tabanan, Bali; and many friends in the three villages, one in Yogya, the second in Tabanan, and the third in Gianyar, Bali, where I lived between January 1971 and June 1974. All of them showed unfailing patience and good spirits as I went about trying to learn languages, gamelan and how to act with at least some small degree of what the Javanese and Balinese have so much of, sensitivity to what's going on around you.

1. (New York: Harper \& Row, 1969), p. 18.

2. My research on Java was done in the Special Area of Yogyakarta, where I lived for a total of twenty-nine months, 1971-1972, and January through May 1974. When I speak of Java and the Javanese, I speak of the people of this area. While within Central Java most generalizations about "the Javanese" hold as true as generalizations about people can ever hope to hold, in East Java there are differences which I myself cannot speak of from any experience. The presence of another language and culture in West Java makes it an altogether different case. 
My contention is that there are quite strict limits of prerogative in Javanese social behavior, lines beyond which a Javanese feels no longer permitted to influence, nor responsible to, others. I think this social discretion is congruent with what could be termed the musical discretion that governs the organization of Javanese gamelan.

Speech Levels and the Range of Styles

The most striking element in Javanese social encounter is speech levels, the use of different words and affixes according to the relationship between speakers. In two articles in Indonesia, 3 soepomo Poedjosoedarmo has given a complete account of the formal basis of speech levêls, the use of different vocabulary sets to make up a total of nine distinct types of speech. I would like to give a much briefer description of the levels but add a bit about their use in different kinds of situations. The three principal levels are ngoko, madya and krama. ${ }^{4}$ The vast majority of words in Javanese are "unmarked," they have only one form. Of the words with more than one form, a child learns those classed ngoko first. A person thinks in ngoko (except when his thoughts picture conversation with another person). Krama provides other words--about eight hundred and fifty lexical items (according to $\mathrm{Dr}$. Soepomo) plus alternate forms for verbal affixes and other particles, their meaning precisely the same but reflecting differently on the relationship between speaker and addressee. Ngoko is used among intimates--relatives or close friends of roughly equal status--and by superiors to people of considerably lower status. Krama implies distance, respect, politeness. It is used among persons of high status who are not on familiar terms, on the part of inferiors to superiors, and in addressing groups. In a way the most interesting level, because the most flexible, is madya. There are only about forty specifically madya words. All the other words used are drawn from other vocabularies, the blend of ngoko and krama being at the discretion of the speaker. Like buying Sunoco gasoline, using madya means coming up with your own mix--instead of octane rating, the sliding factor is "respect." A11 of these levels permit as well the use of two special sets of vocabulary: krama inggil, honorifics to show special respect to the addressee or to a highly respected third person, and krama andap, words used to humble oneself in deference to the second or a third person, or in some cases, the second person in deference to a third. Also situations requiring pure krama, rather than some blend of madya, usual1y require krama inggil and $\mathrm{krama}$ andap. In ngoko, the use of these special forms about the second person indicates familiarity or affection plus respect--it occurs quite rarely and usually only among high status speakers. In madya, their use is, again, at the discretion of the speaker and may be irregular, so that a speaker uses some but not all of the krama inggil vocabulary to his interlocutor. Finally, there is a small set of kasar words, vulgar words referring to bodily functions, used in anger and jokes. 5

3. "Javanese Speech Levels," Indonesia, No. 6 (October 1968), pp. 54-81; "Wordlist of Javanese Non-Ngoko Vocabularies," Indonesia, No. 7 (April 1969), pp. 165-90.

4. The a's are pronounced like the au in caught, as is the final a in madya. I have used standard rather than phonetic speliling throughout this paper because for the most part Javanese and Balinese are spelled phonetically.

5. High Javanese does not really provide euphemisms for these things. There are not just low, but also high forms for words that in English can hardly be mentioned in "polite circles." For example, there is a krama inggil form for the verb "to fart." 
Soepomo 1 ists nine distinct ways in which these vocabulary sets can be combined, each combination having its own name and function. These nine combinations represent the language at its most nuanced. Actually, few people outside the palaces of Yogyakarta and Surakarta are aware of or can manipulate levels so intricately.

The difference between krama and ngoko is conceived by the Javanese as following the distinction--really a continuum--between the qualities of alus and kasar. The selection of speech levels, that is, which of these qualities is appropriate to an encounter, depends on further oppositions: familiarity versus formality, and low versus high status.

At their simplest, alus means soft to the touch and kasar rough. In speech, and behavior generally, the terms distinguish between elegance, restraint and formality on the one hand, and direct expression on the other. The opposition when applied to vocabulary sets depends on the kind of arbitrary valuations that cultures assert and people assume. There is no more reason that mlaku should be ngoko and mlampah krama, than that mlaku should mean "to walk" in the first place. But the Javanese have a rare sensibility to sound, and the elaboration of speech levels plays on opposing sounds to a considerable extent. 6 The most pervasive marker of pure krama is the suffix-ipun for -é in ngoko. This suffix (equivalent to -nya in Indonesian) is used in a way somewhat similar to the in English, in any case with extreme frequency. So the shift from one to two syllables and from an open to closed syllable is remarkable. (It is my impression that krama is characterized generally by more final closed syllables than is ngoko.) Many high frequency words are longer in krama than in ngoko (for example, punapa krama for apa ngoko "what," sampun krama for wis ngoko, a time marker meaning "already"), tending to slow down and draw out any utterance, a desired effect when speaking krama. All of these sound changes set krama apart from ngoko aurally as well as socially for its reflections on a relationship.

Certain set phrases in krama have a heavily stylized intonation pattern. They are used at the limits of encounter, at beginnings and endings, on entering a house, taking one's leave, in ritual situations and so on. For the rest, krama intonation shares most of ngoko's intonation patterns, but the greater number of syllables and the desire for more modulated tones necessarily affect their shape. The difference in content, which I will speak of later, of course influences the intonation patterns used as well.

Ngoko is wild. Benedict Anderson has aptly termed its sound "staccato."7 Jagged, abrupt, mercurial also give some idea of its possibilities. Spoken among good friends enjoying themselves, its intonation swoops and soars while the words pour out at a great clip. Peasant women, especially, make frequent use of a change in register, going off in a shrill shriek to contrast with the rather deep, flat tones of

6. So, for example, $-\underline{i}$ in ngoko often changes to -os in krama (as for example, genti ngoko, gentos krama, to change); - $-\underline{a}$ in ngoko to -nten in krama (segara ngoko, seganten krama, ocean); and -bu in ngoko to -bet in krama (mambu ngoko, mambet krama, to smell).

7. See his "The Languages of Indonesian Politics," Indonesia, No. 1 (Apri1 1966), pp. 89-116, and "Notes on Contemporary Indonesian Political Communication," Indonesia, No. 16 (October 1973), pp. 39-80. 
their normal speech. Unlike krama's even volume, ngoko permits both full voice and stage whispers. To emphasize (mbangetaké) a description, initial consonants can be followed by an infixed $u w$ or $i y$, and voiced consonants, already heavy in Javanese, are exaggerated. So gedé banget, very big, becomes guwedé buwanget, $\mathrm{g}$, $\mathrm{d}$ and $\mathrm{b}$ all very heavily voiced in an explosion of exclamation. Such ploys are considerably restricted in krama. In madya, the extent to which one indulges in such effects indicates higher or lower mixes.

As mentioned before, it is the percentage of krama and ngoko words that matters in madya, more than which particular terms are drawn from each. Certain words--personal pronouns, references to the addressee's body, and verbs connecting speaker and addressee--are more highly marked. At either end of the spectrum of madya, too, there are patterns concerning which words are the first and last to be shifted. So the first word indicating madya rather than krama is the use of sing (ngoko) for "which," rather than ingkang (krama). At the other extreme, the words that mark off low madya from ngoko are mboten (krama) rather than ora (ngoko) (a negative particle) and the first and second person pronouns. But within such limits the speaker has free rein and can even use now the ngoko, now the krama term quite inconsistent1y, as long as he keeps a fair control of the overall percentages.

What a person says is also closely linked to the opposition of alus and kasar. In krama, circumlocution is values, whether in the form of established phrases like kanca èstri (kanca = friend, èstri = woman) instead of sémah, krama for one's wife, or more generally, by softening statements, so that one says kirang saé (kirang = less, insufficiently; saé = good) rather than awon, krama for bad. To be forceful in one's opinions implies conceit, a brittleness out of keeping with krama's accommodating deference. Discussion may involve a difference of opinion, but the difference must be constantly deemphasized in favor of grounds of general agreement. So one person will frequently listen to someone else's point, repeat it in its entirety while expressing his full agreement, and then say, "I would like to add. - : to make his own, perhaps quite contradictory point. Among new acquaintances, conversation is an effortless stream of established questions and remarks that are neither cold nor familiar but rather generally affable. Westerners tend to take exception to this patter, considering it at once boring and false. To the Javanese, it is the oil that keeps the wheels of interaction in smooth motion, not an affectation but an obvious way to act in the presence of someone one knows slightly. In addition, it sometimes provides information needed to establish relative status, and, hopefully, to uncover a relationship of common kin or friends.

Certain situations require complete and preferably flowery krama: formal gatherings like meetings or social functions, and certain situations concerned with rites of passage. This extreme formality in no way embarrasses the Javanese. So the presentation of mas kawin (bride price) in the village where I lived occasioned an extraordinary display of formalized speech and gesture, and this between men who otherwise would use ngoko or madya. In fact, between the formal statements required, they talked informally, choosing speech levels as they would in everyday interaction. But as soon as anyone started speaking formally to the group, backs straightened and speech returned to the most florid reaches of krama. The sudden shift required no apology or dissimulation.

Ngoko permits the direct expression of opinion, sarcasm and abruptness. The polite phrases of krama andap such as duka, inggih (from 
nyuwun duka, I request your anger, that is, I'm afraid I don't know) are replaced by curt monosyllables (mbuh, I dunno; moh, I don't wanna). A quick put-down is roundly enjoyed by a group of people on familiar terms, something inconceivable in krama, where at most a veiled insinuation is possible. Ngoko is the language of humor and love. Jokes are almost invariably in ngoko. It is standard to give the punch 1 ine of a joke in ngoko in a situation otherwise requiring pure krama. In fact, the sudden shift carries much of the effect. Love, at least as passion, also necessarily implies the intimacy of ngoko (a1though in literature, considerations of status may still influence the woman's expression). The nobler sentiment of tresna, devoted affection to kin or spouse, accommodates the elegance of krama more easily, although I believe this use of krama rarely occurs outside the noble families of Yogyakarta and Surakarta. Anger can only be openly expressed in ngoko.

Gesture is marked in Java in the same way as speech. The same attention to relative degrees of refinement in speech applies to the way that people sit, stand, walk, move their arms and hands, hold their shoulders and so on. 8 The more alus one's speech, the more restrained one's motions. It is not precisely a question of control, which implies tightness, but of composure. Alus movement should be effortless, apparently (and in larger towns, often) unthinkingly elegant, with no sudden, jerky motion to interrupt the impression of calm. (A Westerner's gait, forward full throttle with the whole torso turning as the arms swing, strikes the Javanese as a sign of unqualified arrogance.) There are many stereotyped gestures indicating refinement: a person points with his thumb, the fingers folded; when passing in front of someone, the body is bent at the knees while one arm is extended toward the floor and the other held close to the chest, and so on. As in krama speech, of course, elegance in action suits some people better than others. In many people, the polite smile takes on a hideous leering quality and the lowering of the body, which should be accomplished by bending the knees more than the spine, looks more like a pained stoop. But the ideal is there, and to see one of the people in the towns of Yogyakarta or Surakarta--now almost all over fifty years old-to whom being alus is "natural" is to see how elegant restraint can be.

By the same token, Javanese men may sit properly with their heels pulled up on their seat, or they may lean on their friends or lie about on mats, propping up their bodies with an elbow. The contrast comes out clearly at a village performance of wayang (shadow puppet theater). From the beginning of the performance around nine in the evening until the gara-gara, around midnight, the male guests sila (sit cross-legged) formally before the screen. After the gara-gara, their responsibility as guests has been fulfilled and they are free to leave. Other spectators, mostly boys and young men, then come streaming in to spraw1 in great heaps all over the floor, staying till morning to watch, joke with their friends and sleep. (Women profess little understanding or interest in wayang. They may sit in a special area, far behind the men, if they wish, but few stay for very long. On the other hand, they often

8. Javanese women tend to exaggerate their speech, and in fact all gestures, more than men, whether toward the elaborate politesse of krama or the enthusiasms of ngoko. But they are also more apt to adopt a certain playful irony toward whatever stylization they assume. In fact, beyond initial encounter, it is men who will watch their krama quite carefully, whereas many women will opt for a more familiar tone. Men must generally be more concerned with reflections on their dignity. That, I was told, is why men who wish to buy something don't bargain well--they get embarrased at the haggling and give in where a woman would keep right on bargaining. 
take an avid interest in ketoprak, folk drama, and assure themselves ringside seats for the duration of the all-night performance.)

The pertinence of touch is a function of the importance of gesture generally. Touch in krama relationships ${ }^{9}$ is if anything more difficult than in America. In a store, a customer places money on the counter and the salesman picks it up, rather than pass it from hand to hand. But in ngoko relationships between people of the same sex, touch is not only permissible but a principal expression of friendship. In a village, it is only once men are about forty years old or more than they cease to sit leaning, or lying, on their friends at an informal gathering. (Touch between the sexes in public, except among the most modern of young peqple, is out of the question.)

Using Speech Leve1s

Given the above outline in the stylistic differences between krama and ngoko expression, the next point is, how are they applied? Birth, education, employment, wealth, sex and age all influence status in Java. A member of the court nobility has, obviously, high social status. Higher education, white collar work and wealth all imply high status and usually come all of a piece. Men enjoy superior status to women, in that it is considered a woman's place to defer when important decisions are made. (Although practice is hardly so simple as that statement implies. 10 ) Age is, in a sense, the last issue to be considered, but, if other factors are relatively equal, it is important, enabling the older speaker to be less formal. Even if a younger speaker is of much higher status--better educated, wealthier, and so forth-he will usually indicate some measure of respect for an addressee's greater age.

Familiarity is, of course, implied within the nuclear family. Close relatives, at least in villages, tend to use ngoko exclusively. Some children will come to speak some degree of madya with their fathers by the time they reach adulthood, but I observed no villager who spoke anything but ngoko with his mother. This difference reflects the usually greater warmth in ties between mother and child than father and child beyond the age of about seven or eight years. Older siblings may be addressed by younger siblings in madya in town, but this I only saw rarely. The strict use of complete krama towards one's parents and older siblings now applies only, I believe, to the nobility. In-1aws often speak madya, even when they live in the same house.

Widely divergent status usually precludes the possibility of intimacy. But equal status does not necessarily imply familiarity. Situa-

9. I will use the term krama and ngoko relationships, not a term that exists in Javanese, but which is justified by the links between levels and behavior generally.

10. Although Javanese will say that a woman must respect (ngajèni) her husband, to apply our ostensibly transparent notion of relative status to Javanese relations is particularly absurd in the case of the sexes. Actually, each section of my discussion of language and interaction should be qualified according to either sex. But in fact my status as a young single male (aside from being a landa, foreigner) necessarily limited my field of vision, and consequently my competence to speak of the feminine viewpoint. Most of my remarks in this paper--and I must thank Ben Anderson for pointing it out--apply first and foremost to males. 
tions in which an American is liable to assume an easy-going informa1ity of speech and manners may not evoke such a response in Javanese. Many university students will maintain krama or a high madya with some of their fellows indefinitely. At the other end of the social scale, a surprising number of men in the village where I lived, most of them with little education beyond primary school and few other differentials in status, spoke to each other in madya. This pattern included young unmarried males, who have the greatest freedom of action in Java. Within the village, most of them spoke ngoko with at most four or five people outside the nuclear family. Among educated people, wives will use ngoko plus krama inggil when speaking to their husbands. In villages, the krama inggil is not so essential.

In "impersonal" relations, the use of krama or madya depends on the speaker's estimation of the other person's status. So in the market, madya is the rule; in stores, madya or krama; in offices, krama. In sum, the great majority of a person's relationships are in madya or krama, not ngoko, although the bonds of greatest affect are in the latter.

The uses of krama that I have mentioned would be explained by the Javanese as a function of "respect"--ngajeni wong (literally, to value people). "Respect" does not depend on one's evaluation of another person's character. A person's status, of course, is crucial to the degree of respect he must be shown. His behavior is also a factor--if you speak alus, Javanese often say, people will respect you. At the same time, how people treat you also determines whether still other people will respect you. A newly married man explained to me that the difference between being married and bachelorhood was that you had to be more careful to see that people showed you respect. "You can't play with children so much. They may not be able to basa (1iterally, "language," but used as a verb to mean, to speak in krama or madya) and you'11 kena saru (kena = to suffer a blow, etc., saru = obscene, or, as here, improper or disrespectful)." The last phrase, rather 1ike getting splattered with mud, illustrates to what extent one's respect depends on what happens between people, rather than qualities inherent to oneself. Another newly married man complained that his wife was too familiar with people and even made improper jokes. As a result, she was ora kajen (not respected, kajèn is an impersonal passive), something that could never be remedied, and he, in turn, would suffer the same ill effect.

It must be stressed that the vocabularies of speech levels are quite generally known throughout Central Java, or at least the southern portion of it. Some terms of krama inggil may not be known to a villager, but the great majority of krama words are common knowledge. In this respect, ability to speak krama is not a class marker--this contrary to most city dwellers' opinion that no villager can speak krama we11.I l Yet it is true that to speak with the effortless elegance which is the essence of alus behavior requires exposure to the aristocratic circles of town. Here it is not just vocabulary but intonation and turn of phrase which distinguish the experienced speaker. Madya is

11. Hence the disdainful remarks about krama désa (village krama)--the rendering of words, especially place names, into non-existent krama forms. Although city people seemed to think the practice rampant just outside the city limits, and villagers where I lived thought it so just a little further out toward the mountains, I actually only encountered it in one area, high in the mountains of East Java. 
in a limited sense linked to low status, in that educated people regard madya as the speech of peasants and are relatively reluctant to use it with other educated people. They do use it, however, and not just with low status speakers, because there are certain types of relationships-with, say, a fellow kampung-dweller (kampung = neighborhood in town) whom one has known a long time but who is not really a close friend-for which it is most suitable.

The system of relative status, in fact, rarely operates in absolute terms. Even if two speakers are of clearly different status, an educated city-dweller and a bëcak (pedicab) driver, for example, they will not usually speak in pure ngoko and pure krama respectively. Instead, they, will speak in differing degrees of madya. In such situations, a certain reciprocity operates: the most alus the higher status person chooses to speak, the more alus his interlocutor's speech will be, although the starting points are of course far apart.

With so many factors operating on the choice of speech levels, and so many refinements possible, it might seem a very difficult task to select the proper level on meeting a stranger. Actually, a few readily observable signs take care of most situations. The most obvious is dress. If a person has on good quality western-style clothes, or a fine batik, the chances are that complete krama is in order. A man in an old shirt and shorts is probably a laborer of some sort and so some degree of madya is in order. Beyond dress, a few questions will fill in whatever information is needed--the addressee's work, where he lives--and also indicate his tendency toward more or less alus behavior. Here personality enters into consideration. Its role is usually overlooked in discussions of speech levels, but it is crucial.

Every speaker of Javanese is constantly making choices when he speaks, choices that reflect on his view of his addressee's relative status and on the intimacy of their relationship. But the way that he makes such choices necessarily reflects on his own personality, because the criteria are really quite vague. While the quality of alus is idealized as a virtue, other qualities are available to counterbalance it. A person may command respect for his ability to get things done, even if that ability depends precisely on his willingness to act more forthrightly than is usually considered proper. Or he may be appreciated for his straightforwardness and a sense of humor that depends on that undauntable frankness. In fact, the choices are rarely absolute, but a tendency toward relatively alus or kasar behavior quickly becomes apparent in any encounter, especially since not just vocabulary, but also linguistic content and gesture carry the message. Some people prefer to maintain a level of formality that others find stiff. If two such differing individuals of similar status meet, the more easy-going person will tend to bring the level of speech down. His interlocutor will follow because it would be inappropriate and demeaning for him to respond in a consistently higher degree than he is addressed in. But he may wish to apply brakes. For example, since in Javanese one answers an interrogative verb in the positive by repeating the verb, if A says in ngoko, "Isa?" (Can you?), B can answer in krama, "Saged." (Yes, I can.) and the immediate contrast shows that $B$ would prefer not to be so familiar. A will usually be embarrassed enough to shift upwards. But al1 of these maneuvers must be accomplished with apparent unconsciousness on the part of all speakers. People very rarely discuss the speech level they use, unless some event like marriage significantly and suddenly changes their relationship. 
I have tried to show how various oppositions motivate speech levels and encounter generally in Java. It is the peculiarity of Javanese not that these possibilities exist, nor that they tend to link together (formality in speech with restraint in sentiment, for example) but that they are all subsumed as marked elements in what comes as close, I think, as any culture comes to defining a system of face-toface interaction. Means of expression, styles, are provided cultural$1 y$, and much of their expressiveness derives from their inclusion in a set of marked pairs. Krama's muted elegance depends for its effect on its opposition to ngoko's raucousness. And the fun of lying across someone's stomach at a wayang certainly stems partly from the physical distance implied in krama. The Javanese are not graceful puppets. They do not prize either formality or informality as good in itself. Instead," they praise the ability to be luwes, to act appropriately in any situation. Being luwes means having a sensibility to the play of oppositions and distinctions which give form to Javanese relationships.

\section{The Ground Rules to Interaction}

While the notions of alus versus kasar and formality versus intimacy are known and talked about by the Javanese, other ideas about encounter which are not so explicitly stated appear in the ways that they interact. These ideas concern not the stylistic alternatives an actor can choose from, but the given rules which apply to all types of encounter. Actually, ideas is what I am not talking about, because while the rules to interaction may differ from culture to culture, within any one culture they neither are nor need to be formulated consciously. So an outsider has to try to discern patterns in Javanese behavior and trace their image on another surface. At best shadows cast by living forms, analytical remarks about how real people get along with each other can only hope for the clarity of silhouettes in compensation for their awful flatness. This is the more true in that any description of Javanese behavior inevitably relates all the things that do not happen. What follows is really no exception, although I hope to illustrate the blanks with a few views of real people.

Much is made in Western accounts of the Javanese reluctance to express negative emotion. That reluctance certainly exists and certainly is remarkable. But I think it can be situated in the context of Javanese interaction more generally by linking it not, as is often done, to the notion of alus alone, but to a broader and vaguer notion of the imits of interaction.

Let me go back to speech levels for a moment. Depending as they do on considerations of two speakers' relative status and familiarity, speech levels make interaction unequivocally one to one. Every pronouncement places speaker and addressee in a single link, quite distinct from the relationships each party has with other people, present or absent. Surroundings do not influence a relationship. That is, if $A$ and $B$ speak ngoko with each other, they will do so in the presence of $C$ no matter what the status of $C$, or the links $A-C$ and $B-C$ may be. (Rare exceptions are cases in which $A$ and $B$ consider it important that $C$ notice their mutual respect, as, say, two teachers in the presence of a student, and in very formal situations like meetings in which questions of role completely overshadow those of personal ties.) If $A$ and $B$ are in a ngoko relationship and $A$ and $C$ in a krama one, then every time A turns to speak to one or the other his speech will shift. As speech levels, beyond initial meeting, are so nearly automatic (at least as long as no one feels the need to shift), the change is not 
remarkable to the speakers involved. People do occasionally slip, but they simply repeat what they have said, changing it to the proper level with little embarrassment. In the case of madya, a speaker $A$ who speaks differing degrees of madya with $B$ and $C$ will modify the mix as he looks at one or the other in the course of speaking. The strictly binary nature of relationships underlies a very common feature of Javanese speech: to quote, or practically reenact, a previous conversation word for word rather than give its sense.12 Rather than say, "Lik Nar asked me where I was going and I said to the spring," a person named Surono will say, "I saw Lik Nar on the path. 'Where are you going, Su?' "I'm going to the spring, Lik Nar,' I said." The technique preserves the speech levels since no matter whom Surono is recounting this to, he will quote the levels he and Nar actually used. It also maintains the terms of direct address (as here $2 i k$, for bapak cilik, younger brother of a parent) which place a11 Javanese speakers in real or fictive kinship relations. These indicators are clearly as important as the specific content of the remarks.

The use of krama inggil and krama andap in reference to a third person implies another binary relationship, either I-he or you-he, quite distinct from the I-you at hand. It is for that matter the field between any two actors that receives the greatest elaboration in these vocabulary sets. Most of those few verbs with a lexical item for every category of vocabulary are those that connect two actors: to give, to ask, to ask for and so forth. It is also significant that the range of second person pronouns in Javanese in so large and flexible, yet the inclusive we (interlocutor and I) is so problematic it is usually avoided altogether.

\section{The Stuff of Conversation}

The Javanese language focuses attention on one to one encounter. So then what happens? A Westerner's initial reaction is to say: very little. Rather than explain what does not happen, though, I would like to begin at least by describing the forms conversation assumes. For village men, the most frequent form of socializing is jagongan, the evening gathering of men at the home of a family with some ritual responsibility. Almost all rites of passage require at least one, sometimes as many as twenty-one to thirty-five nights of jagongan, some including a slametan (the ritual distribution of food). Mats are spread on the floor and men start arriving around eight or nine, to stay one hour, several or all night. Older and higher status men sit near the point furthest from the door. A radio is kept playing all night, while the main entertainment is gambling with Chinese cards similar in principle to dominoes, or with Western cards. At any given moment, perhaps half of the men present will be playing. The others may be talking among themselves, but it is more likely they will be sitting watching the players, or sleeping. If they are talking, and at those times, as when there is a slametan, when formality is in order and card-playing frowned upon, the conversation was until recently certain to concern lottery numbers. Until January of this year, a lottery number was drawn in Yogyakarta and announced over the radio every night. People of both sexes and all ages bought tickets daily--the person over

12. Word for word as the speaker chooses to recall it, of course. I was always delighted at how colloquial my Javanese got in the retelling. Everything tends to get repeated, too, even the Kula nuwun and Mangga which begin every visit in Java and so could presumably be omitted without endangering the sense. 
ten years old who did not buy a ticket was the exception. In town, Chinese sold ramalan (prediction) sheets covered with Chinese and Javanese symbols and a profusion of numbers, plus enigmatic phrases, arrows, 1 ines and asterisks. The interpretation of these sheets was stuff for endless conversation. What with the vast array of possible combinations, every day the number drawn either appeared on or could be derived from some reading of one of the sheets. Dreams and incidents in the course of the day could also be taken as signs. All were discussed at enormous length. The point is that Javanese men clearly find this type of conversation, quite unrelated to their surroundings, to their opinions of things, in fact, to people, eminently enjoyable. Now that the lottery has been (temporarily?) stopped by the government, conversation tends to concern the card playing, still the standard activity at jagongan. But in fact, without their favorite topic to discuss, the men mostly just talk less. Neighborliness only requires looking in once or twice on a jagongan at one home. But most men return night after night, rather than visit neighbors individually. The latter would permit gossip, which in the public setting of jagongan is, to the Javanese, unthinkable. But gossip did not seem nearly so interesting to Javanese men as to their wives, or say, American academicians. I was astonished at how slowly gossip traveled among village men. Nothing could differ more sharply, moreover, from the fervid political debates of an Arab coffee shop or the rowdy fellowship of an English pub, than the endless round of cards, numbers and sweet tea that is an evening's jagongan. 13

\section{Social Agreement}

Conversation does of course sometimes take a more sustained form. But there is a peculiarity to Javanese conversation common to ngoko and krama, village and town: the constant reappearance of set phrases and thoughts. Every language has its clichés. Part of the fun in learning a foreign language is coming to have the proper sentiments. But in Java their ubiquitousness is startling. These little designs in the weave of conversation give every encounter a measure of established form. If a person arrives somewhere to find another visitor already there, he asks, "Have you been here long?" The answer is either, "I just got here," or, "A little while." There are no other possibilities. When any two people have been together for any length of time and one is going to leave, he requests permission or at least says, "me first, okay?" (This applies to bathing at a spring as much as to visiting someone's house.) If a person expresses an opinion or explains a point, he invariably adds, "That's just my opinion, though. I don't know what other people think." If people in a village gossip, they refer to people not by name but as "the people there to the north." But in fact, the predictability of things goes deeper than these little loops.

During my first several months in Yogyakarta, I was often surprised, and a little miffed, at the way that people would very, very frequently tell me that there were levels in Javanese. "Kuza is alus,"

13. The degree to which the character of social gatherings is conditioned by recent social upheavals in Indonesia is impossible for me to tell. From the outside, Indonesians' ability to speak unthinkingly and even freely about the events of 1965-66 is eerie. In context, and to a person who did not know pre-1965 Indonesia, it seemed strangely reasonable. Perhaps because the particular hamlet where I lived was relatively little affected--directly--by the events, to the inhabitants the issue was settled and seemed neither very interesting nor very problematic. 
they would invariably say, "aku kasar." Especially if they had already seen me speaking krama, madya and ngoko, it seemed to me incongruous that they should think they were teliing me anything new. It was only once I noticed Javanese telling other Javanese the same thing that I began to see that the communication of information was not the point at a11. The same pattern appears in the statement that the staple food in Java is rice. People at jagongan often asked me what the staple food in America was (usually knowing full well that it was bread and paying scant attention to any other answer I might come up with). Then, turning to another person, they would say, "Nèk tumrap wong Jawa, makanané pokok rak sega."14 (As for the Javanese, it's rice, isn't it?) The rak, like the "isn't it?" some Englishmen add to a sentence, is not a question but an invitation to agree. Agreement is precisely what happens in Java, on the part of all present, and agreement is, I think, what was aimed at in the first place. Javanese conversation abounds in these points of universal agreement. Not just the thoughts, but the phrases and illustrations used are total1y set. So any discussion of religion invariably, and almost immediately, resolves into the statement, "All religions are really the same. They all aim toward the same end. They just take different paths. Like if you and I were going to the Alun-alun (town square), I might go down Malioboro and you go via Kota Baru. But we'd both end up at the Alun-alun." The illustration is as formulaic as the thought expressed. To Westerners, such conversations are platitudes, the weights which keep Javanese conversation from ever getting off the ground. To the Javanese, quite the opposite, they are points of contact between the speakers and are essential to the smooth flow of the conversation. While a quick wit is appreciated in Java, one feels little incentive to the crafting of original opinions. Instead, a good conversationalist wends a graceful way from one generally acceptable point to another.

When there is business at hand, particularly business of a delicate nature, there is an astonishing inflation in the use of these points of contact. An example was the return of a bull that got loose

14. Here, as in many quotes I have given in this paper, the language is an ungainly mixture of Indonesian and Javanese. Some Indonesian words and phrases have come to be used almost to the exclusion of their Javanese counterparts, in villages as well as in town (as is biasa Indonesian, for lumrah ngoko, limrah krama in Javanese). Many other words and phrases are borrowed from Indonesian more ostentatiously. Village officials and men who work in town are especially given to mixing Indonesian words and phrases into their conversation in order to make a pronouncement sound more forceful or official. If Javanese is rich in the vocabulary of textures and politeness, Indonesian has a wealth of terms and phrases with which to handle the bureaucratic side of life. The pomposity implicit in their use is not lost on villagers, who will often speak Indonesian to their friends in mock seriousness.

Some people in town, and in a very, very few cases village youths with claims to advanced education, find Indonesian the most suitable language for a particular relationship. Village women, including young women who know Indonesian quite well, are often reluctant to use Indonesian at all and will do so only with a non-Javanese--although they, too, use the words most commonly taken over from Indonesian. (The attitude of some older village women toward Indonesian verges on defiance. Whenever any non-Javanese came to the door of the house where $I$ lived, the older lady of the family would announce loudly--rather more to the general public than to the person at the door--"Basa Mlayu ora isa aku!" ["I can't speak Malay!"], turn on her heel and head straight for the kitchen, laughing in a mixture of embarrassment and wicked glee at what in any other circumstances would be an unpardonable breach of conduct.) 
and wandered into the village where I lived from another hamlet one night. The next morning its owner reported the bull's disappearance through the kepala dukuh (hamlet chief) to the kalurahan (village) office. There the security officer and kepala dukuh of the finder's hamlet were contacted. In the end, the intermediaries, totaling five, discussed and settled the proper procedure for returning the bull and the reward to be given to its finder. Arriving at the sum took a fair amount of bargaining, but bargaining constantly interlaced with three "proper thoughts": that this was a case of "musyawarah"--open discussion in which everyone could express his own views freely; that this situation could be likened to having a child who has wandered off and whom a neighbor helps you to find; and that the sum involved was definitely not to nebus (tebus = to reclaim by paying a fee, which is exactly what this was) but rather uang lelah (Indonesian: uang = money, Zezah = fatigue due to effort). When the owner of the bull arrived, it was insisted just as emphaticaily that the money was not uang lelah but rather tanda terima kasih (also Indonesian, a sign of thanks). Everyone repeated all of these phrases an astounding number of times, to the agreement in unison of one and all. The discussion took about three hours.

The difficulties in the sjtuation were several. The problem really only involved two people, owner and finder, but two people with no connection other than the issue at hand. When it comes to money and possessions, the Javanese extend no a priori trust to anyone at all. Therefore the incident was a possible source of tension (the finder might be thought to have actually stolen the bull) and the gap had to be bridged by several intermediaries who knew each other personally, and could be connected in the concord of identical opinions. The incident illustrates the absence of any but a rather clumsy machinery by which social disjunction can be overcome in Java, 15 and the insistence that mediation be accomplished in an atmosphere of universal agreement.

The greater distance implied in krama relationships calls for especially frequent recourse to established thoughts. Conversation in ngoko rests on the same principles, however. Mention of politics, religion, mysticism, language, foreigners, varieties of rice--almost any topic will evoke certain given ideas. I do not think this pattern should be considered mere dissimulation: I was only rarely aware of any alternative views to the subject at hand, no matter how close a. friend I was speaking with. Complaints are sometimes voiced, even in the political sphere. But they are as set as any other ideas expressed. 16

\section{Social Disjunction}

The tendency to generally acceptable sentiments and opinions has a negative counterpart. The Javanese are very reluctant to cross wills. Mockery is possible provided one clearly shows at least a pretense of

15. Also expensive. The sum decided on was $\mathrm{Rp} .2,500$, one tenth of the bull's value, of which Rp. 500 went to the man who found it and the rest was divided in differing amounts among the intermediaries.

16. The current government does not, of course, encourage criticism. But I did not sense the kind of muzzled silence on this subject as I did on some others, closer to home. That is, criticism of which no government official would have approved was frequent. But these criticisms, too, were formulaic. 
joking. True difference of opinion is difficult to express in Java, direct criticism almost impossible. If in formal situations the result is a retreat to common ground, in ngoko relationships between intimates, it is silence. The family with whom I lived had close to threefourths of a hectare of rice land. The elderly father told his third, unemployed son that he should work it, rather than sharecropping the land out. He, the son, said no, and the discussion was closed. No pressure was laid on him. The hamlet was full of unemployed youths, some of whom freely admitted to having dry land which they hadn't the energy to work. Their families exerted little pressure on them to do so. The treatment of small children is similar. If a baby picks up a knife, his mother does not wrest it from his immediately, but rather tries to attract his attention to something else. Once my neighbors left their two-year-old son to visit his grandparents in another hamlet for a couple of days. When his mother went to get him, he refused to come. She was in tears when she told the incident that evening, but when I asked why she didn't insist that the boy come back with her, she said simply, "He didn't want to." He decided to come home close to a month later. Much of the development of feelings of isin in a child (malu in Indonesian, usually translated shame or embarrassment) depends on coming to feel reluctant to express or impose one's will forcefully on a person or situation. 17

Anger, hurt feelings and even annoyance rarely surface openly between two persons. The Javanese do feel such things, of course, but they prefer silence or complaining to a third party over confrontation. In fact, in little but still remarkable ways, they succeed in their own ideal of not feeling anger. If two bicyclists collide but with no serious effects, they are as likely as not to smile--even if one person is clearly in the wrong. In situations in which a Westerner would be considered fully in the right and so justified in making a scene, a Javanese would be praised for restraint and be deemed keras (1iterally, hard, so unyielding, harsh) to insist.18 A man explained that his wife had opened a stand in the hamlet to sell sugar, tea and other staples. Three times, however, they had gone bankrupt because villagers would buy on credit and then default on payments. When I asked if he couldn't demand payment, he said "Mboten tegel kok." (I wouldn't have the heart, or nerve.) It is embarrassing to default on one's debts, but nowhere near so embarrassing as to dun. Nor can any outside authority be invoked to enforce payment. In Java, there is practically no form of social pressure other than the general valuations of how people should act. And while those valuations are phrased positively, in practice they more often take the form of negative injunctions. So it is most improper to remonstrate with a person for failing to fulfill an arrangement, but quite permissible simply not to show up for an appointment. The fact that all kinds of socially "unacceptable" behavior will be

17. The greatest direct parental control is exercised between the ages of five and about twelve years. But in the case of boys, increasing age means increasing freedom to roam about the hamlet and beyond, and so the successful evasion of any constraints that might be laid upon them.

18. While Americans tend to deal with cultural difference by stamping foreigners dirty or backward, the Javanese brand them keras. Keras is not the same as kasar. People often say of someone, "Wongé kasar nanging apik" (He's coarse but a good guy) and here his coarseness usually seems endearing. Keras is never anything but negative. In fact, if the English think the Orient starts at Calais, the Central Javanese seem to think the domain of keras lies perilously close to the eastern edges of Surakarta. 
accepted in silence means that people with thick skins can get away with murder. To give just one out of numerous examples: relatives of people who owned a gamelan borrowed the instruments and took them to their home in the next village west. The gamelan was used in a ritual celebration at their home. The relatives said they were then going to clean it--and promptly sold it. The owners did nothing, saying that making a scene would not do any good--and anyway they "mboten tegel."

People will intervene in others' affairs only if conflict becomes glaringly visible. When friction between a mother and her daughter flared up one morning in the hamlet, and the mother erupted in great streams of abuse, the relatives who came to put a stop to it assumed a studiously calm air. Approaching the pair slowly, the older lady's sons looked disdainfully at them both, while muttering, "All right. That's enough. No more of this." One son told his sister to go to another house, while the other two sons simply stood between mother and daughter. No one asked what was the matter nor was willing to take any part in the quarrel. The point was only to stop the scene, and that in the most apparently casual way possible.

\section{Limits to Interaction}

I do not think the Javanese avoid negative emotions simply because they do not like scenes. I think they have a wider sense of the limits of interaction. That is, they distinguish between contact--in the many different ways expressed in krama, madya or ngoko relationships--and intervention. Intervention does not only mean negative action. Other types of interaction cause uneasiness. Receiving presents is difficult: a present is usually accepted with obvious embarrassment and burrowed away, unopened. Payment of any sort in a personal relationship must be carefully obscured. Asking a person's advice must be done with discretion. No matter how distant he may be to the situation, he is likely to answer with disclaimers to having any opinions.19 To give advice as an older person to a younger one is idealized in Java, but in practice is often liable to cause only embarrassment or impatience. Persuasion is at best indelicate. When the father in the family $I$ stayed with lay sick, his relatives wished that he would take the pills given him by the doctor but would say nothing to him about it. Nor do people seem to wish to inquire into other people's feelings. One evening I sat feeling sad at the death that morning of a youth in the hamlet. The lady of the house, seeing me the next morning, said, "You were looking sad yesterday. But it wasn't anything, was it?" She did not want to talk about what was on my mind. She was expressing the combination of concern and denial that is the quite effective Javanese equivalent to sympathy. Sex gives rise to distinctly ambivalent feel-

19. Hence the common impasse reached when a Westerner asks a Javanese friend to accompany him to the market. The Javanese friend will begin the bargaining but quickly turn to the Westerner and say, "She wants Rp. 150. Do you want to pay that much?" The Westerner cannot hope to get a straight answer right then and there about whether that sum is "too high." Se he feels himself set adrift right at the crucial point. The situation illustrates two points: the Javanese reluctance to get involved in what is really a one-to-one encounter; and the Javanese view that what matters is how high the buyer "dares" (wani) to pay, in contrast to the Westerner's notion of a "correct" price. To the Javanese, the price depends on factors like how much the buyer wants the article in question, and now rich he is--subjects a Javanese would not presume to pass judgment on for someone else. 
ings. Some village men told me that "many people" had intercourse with their clothes on (as otherwise their wives would be isin) and that too frequent sex was debilitating. ${ }^{20}$ Marriage and family 1 ife in general have a peculiar fluidity about them. While children must always give way to and watch out for their younger siblings, there is otherwise little cooperative effort in the sense of two or more people working on a single project. Among males, by adolescence contact is often practically restricted to passing each other in the doorway. Scenes in which negative feelings are expressed openly are only particularly violent instances of the crossing of lines which the Javanese avoid. Fist fights, even among children, are very rare.

If a person's interaction should involve no intervention, one's own mind must be resistant to the impact of events. This resistance depends partly on physical orientation. To be bingung can mean: to be confused as to the cardinal directions; to have lost one's way; or to show signs of nervousness and anxiety. Saying that a person is miring (leans to one side) and holding the forefinger at a diagonal before one's forehead means he's "a little bit touched." Emotionally, one should be tenang, quiet like a still pool. Death, even of a close relative, should be accepted quietly. Anger and grief both make one's heart "dark," or "murky," like water stirred up. In literature, passion is usually depicted as madness, in contrast to the lucid loyalty and devotion of tresna. A person should not ngalamun, sit looking blank or melancholic. To do so means that one's mind is "empty" and as a result especially susceptible to being entered by the sétan (spirits) that cause sickness. To be kaget (startled), the reaction to many kinds of disturbance, carries a much stronger meaning in Java than in the West, because it causes physical effects. People explained that the death of a baby in the village was due to his parents having an argument. The bad feelings affected the mother's milk, the baby nursed, and was kagèt and died. At a different but I think telling 1eve1: while many Javanese have a remarkable feel for percussion rhythms, they never move any part of their bodies in rhythm to music heard on the radio, whether Javanese or Western. At a concert, they may join in clapping rhythmically--but the rest of their bodies remain completely still.

I should stress that Javanese encounter does not seem hedged with nervousness, restraint or secretiveness except in those situations where there is a very real possibility of conflict. A description of what sorts of behavior make the Javanese uneasy might put in mind the stereotyped image of a reserved Englishman whose dignity in public depends on an impervious silence. Quite the opposite is the case: the Javanese can maintain a stream of affable conversation in most circumstances. The rigid silence that reigns among passengers on an English bus would strike the Javanese as grotesque. For that matter, in the past if the distance between two Englishmen were vertical and extreme, a class distinction, little could be said that would be mutually comprehensible. The advantage of speech levels and the "rules" of Javanese encounter generally is that they make speech possible no matter what links do or do not exist between speakers. (Unless, of course, the disjunction could give rise to tension, in which case intermediaries and the kind of verbal glue I mentioned earlier are necessary.)

20. Although I could speak freely with young males in the hamlet about sex, after two years I remain quite baffled by Javanese sexual attitudes. Neither truly prudish nor relaxed about sex, these friends--and some women--could speak scatalogically but rarely seriously about sex. 
Most Javanese enter any meeting with strangers with a poise that comes from being provided culturally with a complete range of ways to speak and act, and even things to say. Among two high status speakers, initial meeting attains a flawless, stereotypical elegance. In encounters among people of other statuses, the air of refinement is less, but conversation is equally fluid. (And silence in the course of a conversation does not arouse nervousness--it simply contributes to the sense of calm.)

To take the above considerations of speech levels and limits of interaction simply to be methods of maintaining social distance would be misleading. It would imply that the aims of Javanese and American interaction are conceived of as essentially similar, only the Javanese prefer to keep a greater level of formality. But Americans tend to conceptualize interaction as the more or less successful bridging of a gap between self and other. "Closeness," an ideal in "meaningful" relationships, means the revealing of secrets, of personal history, of problems as well as ideas. (Among members of the same sex, it does not imply touch. The closeness, unlike in Java, is purely conceptual.) Honesty, even if temporarily disruptive, is necessary to intimacy. The Javanese, on the other hand, do not have notions of intensity in relationships. Nor do they think of selves as lying hidden behind a fog of subjective consciousness. They are concerned with the ways that people meet, with the selection of an idiom that defines their connection. The lines I have spoken of above are not the same as the Western idea of shells that surround unique selves. They are simply the boundaries between distinct (but of course not identical) units. What distinguishes their notion of interaction from ours--if I may try to sum up the points I have mentioned before--is that their does not implicate an interpersonally instrumental or personally impressionable self.

Discretion and Hierarchy

It may seem strange to speak of a Javanese disvaluation of action that impinges on other people when Java is characterized as a hierarchical society, and hierarchy implies disparities in status that assure some people the right to control others. In fact, rather than contradictory, these two aspects of Javanese society dovetail. Many people in Java do, obviously, impose their will on other people, and very forcefully. Among persons of equal status, such behavior of ten arouses extreme resentment--but the reflexes of Javanese encounter run deep and people will usually resist only passively, by inaction, rather than actively. The situations in which giving commands is both normal and socially acceptable usually include clear disparities in status: master and servant, and higher status employee to lower status one. The attitude of master to servant can easily be imagined: the master speaks curtly in ngoko, the servant answers in krama. No trust is normally extended. The lady of the house keeps food under lock and key, setting out what food is needed to cook for each meal. Any personal exchange tends to be highly condescending. The relationships among members of an office are more interesting. Among employees of equa 1 rank, the full range of krama and ngoko relationships is possible and normal, although the giving of advice and criticism of a fellow's work are very difficult. 21 On the other hand, a high status official, par-

21. I know of only one word in Javanese that means to criticize, that in a negative way, nacad, an active verb from the noun, cacad, meaning defect or deformity. I notice in Indonesian publications now appeals for kritik2 yang membangun, criticisms that build, that is, constructive criticism. 
ticularly if the difference in status is large, will adopt an overbearing manner of self-importance almost as a matter of principle when speaking to a lower ranking employee. In this instance, he most certainly can give orders, curtly correct, and criticize the work of inferiors and look askance at any comments from the opposite quarter. All this is, of course, highly relative--and hardly peculiar to the Javanese. It is particularly striking in Java, however, since it runs counter to so many Javanese precepts about behavior. Yet while nobody really appreciates this treatment, I don't think it arouses quite the indignation Americans usually feel in such situations. Because what a clear distinction in status makes possible is command: telling a person what to do, now, with no embelishments whatsoever. But it rules out just as effectively the possibility of any two-way exchange: the relationship is not personal but "of status." Between the easy, uncritical exchange among fellows (which may very well cover intense politicking, of course) and the absolutely unidirectional chain of command, there is really nothing at all in a Javanese office: 1ittle discussion, little cooperation, and finally, very little action.

Idealized Action

S1ipping persistently into the negative, I have spoken of limits, disvalued behavior and administrative ineffectiveness. Let me describe now ideal images of effective action and interaction in Java, one purely individual, the other groups.

In his essay on "The Idea of Power in Javanese Culture,"22 Anderson has shown the way that power and force are distinguished in Javanese political thinking. The need to exert physical strength in order to impose political ends indicates fundamental weakness. An ideal prince does not need to overwhelm people to force their allegiance. Instead, he attracts their loyalty as a magnet draws objects to itself--not by constraint, but by a quality inherent to himself. His energy assures prosperity and harmony, and because of it, his merest gesture effects action. In a much less sophisticated form, I think a similar notion applies to Javanese ideals of personal action in the world, the notion of kakuwatan.

The Javanese firmly believe in the efficacy of fasting, going without sleep, refraining from sexual intercourse, and other ascetic practices. The various mystical sects in Java spin long webs of explanation around these themes. But I am concerned here, not with the theory of kabatinan, as this stream of thought is called, but with what larger sections of the Javanese population think and do about it. Students will often stay up the whole night before an exam in order to improve their chances of passing. Other people will exclude salt from their diet, eat only rice on Mondays and Thursdays, or keep all-night vigil at a holy man's grave to attain some much-wanted goal. But the ideal ascetic exercise is forty days of fasting in a cave, on a mountain or under a large tree. Several people explained to me what happens. After a couple of days, an ascetic's practice causes the spirit of the tree, say, beneath which he sits to nggoda (tempt or threaten) him. It assumes several forms: a snake that is about to bite him; a beautiful woman; a tiger. Most people, of course, would yield to fear or desire. But a strong (kuwat) man will not. Due to his fasting, his

22. In Claire Holt (ed.), Culture and Politics in Indonesia (Ithaca: Cornell University Press, 1972), pp. 1-69. 
breath gets hotter and hotter. It is this heat that bothers the spirit. It can become so great that the leaves of the tree wither and die. Finally, to get rid of the nuisance, the spirit appears before the person and grants him whatever he requests. The aim most people cited as an example was: the right number to bet on in the lottery. Kakuwatan (the substantive form of kuwat, so strength), both the condition for and fruit of tapa, usually implies physical invulnerability, capacity to withstand deprivation, and the ability to cure people and give them ritual advice about dates and so on.

What I find significant about this image is that it is so far removed from action in society as we think of it. A person shows and gains strength by doing nothing, precisely, except memusatkan pikirané (from Indonesian, to centerize, that is, concentrate, one's thoughts). His immobility radiates the power, heat, that achieves his purpose. The result is a kind of influence, not really what we think of as power. Curing usually depends on control over either the malevolent spirits that cause illness, or the spirit of a keris (Javanese dagger) or sword whose help can be enjoined against those evil spirits. The sick person is hardly implicated at all. (In the same way, I was told that jagongan are held because among the people who come, at least one or two are sure to be wong kuwat (mystically strong people) whose presence will scare off the evil-doing spirits who gravitate toward people in ritual situations.) The wealth one can gain comes through the lottery, a source of wealth quite dissociated from social action. This idealized method of attaining wealth contrasts with the belief that people can make a pact with a setan, receiving his help in selling at the market in exchange for the life of one of their children. While some people mentioned other, sinister purposes in seeking kakuwatan--to cause someone to feel love for him, or to cause illness--most people mentioned only morally neutral or noble purposes, relegating the other to black magic. Power here is not based on interaction in any way, but, if anything, on the ability to avoid it, in fact, to avoid any kind of action at a11.

Aside from the ascetic doing tapa beneath a tree, one other more common image to individual kakuwatan exists in Java. Javanese often speak of the dazang, the shadow puppeteer, as the sterling example of kakuwatan: he never tires, he never falters--and he doesn't piss once al1 night! To the outsider as well, the dalang--alone before the screen and from the shadow side invisible, with his back to the gamelan orchestra which plays at a verbal or musical hint, taking on a multiplicity of roles within a world quite closed upon itself--seems a perfect image of the Javanese notion of power in, but somehow always beyond, the world.

Game1an

If individual action is idealized in asceticism, and is best exemplified by the dalang, then some other example must be found to show idealized action in groups, that is, idealized interaction. Gamelan is an ensemble in a society where organizations are for the most part inoperative or non-existent. I would like to analyze it "organizationally," for the way in which its several members coordinate their efforts. I am an enthusiastic (as opposed to skilled) player of gamelan, but musically uneducated. So my remarks are necessarily musically naive and also very selective. 
Javanese gamelan sets sounds floating like flower petals over the surface of a stream. The several shifts in tempo never break its subtle flow toward the final gong. It can have the indefinable, shimmering quality of Monet's water lilies or the bold lines of Mondrian. And it can produce cool, jade-1ike tones that no Western ensemble can match. Javanese gamelan is musically conservative, diffuse, unearthly and profoundly beautiful.

An average gamelan consists of about twenty instruments for each of the two laras, sléndro and pélog (the former is a five-tone, the latter a seven-tone set, each further subdivided into three patet). The several different-sized saron are thick bars of bronze laid over a single wooden resonating chamber, and struck with a mallet with one hand and damped with the fingers of the other. The number of bars to one saron varies from place to place, but there must be at least the six tones (sléndro) or eight tones (pélog) equivalent to our octave. The slentem also covers the range of an octave and plays for the most part the same notes as saron, but it consists of thinner bronze bars suspended over individual bamboo resonators. Its sound has a deep, velvety quality in contrast to the saron's bright, ringing tones. The saron and slențem play the balungan (1iterally, skeleton). Depending on the type and section of gending (musical piece), this may consist of four, eight, sixteen, thirty-two, sixty-four or more basic notes terminating in a gong. Between the sounding of the great gong, a series of sma11er gongs (kempul, handing gongs; and kenong and ketuk, standing gongs) mark off regular intervals in the balungan. Linked to the invariable four beat phrasing of gamelan, these gongs give all gending a consistent symmetry.

The two bonang (in very old ensembles, three) share the saron's striking tone. Each consists of two rows of smal1, inverted pot-1ike gongs, five (sléndro) or seven (pélog) to a row. The bonang panerus extends an octave higher in range than the bonang barung. They play variations on the balungan at double, quadruple, or eight times the balungan beat. In miampah, or mipil, the simpler drum pattern, the bonang panerus plays at double the frequency of the bonang barung. In the livelier, "sassy" (ndugal) drumming called cibzonan, 23 they play an interlocking imbal pattern, the bonang barung playing, for example, notes 1 and 3 , which alternate with the bonang panerus part, 2 and 5 , to give the rippling effect:

followed by ornamentation on the bonang barung. As in a11 instruments apart from the saron and slentem and the gongs, the bonang players select variations at will and on the spur of the moment. They must only be sure to maintain rhythmic coordination and to 1 and on the main note at particular points. In the loud, magisterial gending classed soran--the pride of Yogyakarta--the bonang barung stars, accompanied only by the instruments mentioned so far.

As with the bonang, there are two gènder, barung and panerus. Actually, the slențem is a very large gender. Its two "younger brothers" (as the Javanese refer to smaller members of any set) are constructed in the same way, and have the same tonal quality. However,

23. Ciblonan actually refers to the truly lively way Javanese children can make sounds in rhythm by plunging their hands into a pool of water. 
the slentem is played with one hand, like a saron, while the gender barung and panerus are played with both hands, each one both playing and damping. The gender also have a range of two and a half octaves each. The gender barung plays long variations quite divergent from the balungan, coming together only at nodal points every four, eight or sometimes sixteen beats. (The gènder barung also quite often plays to meet the vocal line, quite distinct from the balungan.) In the quickest tempo, it often simply doesn't play. But it is considered, in the deliberate rhythms of vocal music, the principal--and most difficult-instrument in the ensemble.

The gambang, resembling a xylophone, plays variations often quite similar to the gènder barung but usually at double its frequency. This is possible because its wooden slats, lain over a single resonating chamber, do not require damping. It has a very distinctive sound, which stands apart from the ensemble in a way that the gender's tone does not. The clempung, a zither-like instrument, provides another distinctive sound, spindly like a harpsichord's. It plays variations to nodal points in the balungan.

The two-stringed rebab is played with a bow and follows the vocal line quite closely. When, as often happens, there are two vocal lines, the rebab shifts back and forth between the two. The suling, a bamboo flute, plays what sounds like wildcat ornamentation. While its technique is not difficult, the fitting of its variations to the ensemble is particularly challenging.

In the slow, classical gending of the courts, there may be only one vocal line, that of the pesinden (female vocalist). Vocal line should not be taken to mean melody, however. Sindènan consists of long phrases that weave in and out of the instrumental 1 ine, and if there is one, the gérongan (unison vocal part for male "chorus"). 24 Forced to point to a distinguishing melody in a gending, one might single out this gérongan as the most immediately accéssible. However, large sections of many genḍing are lacking in gérongan, and when present they hardly predominate in the total effect. 25

24. The 1ong, graceful lines of sindènan resemble, in a way, the "casta Diva" in Bellini's opera, Norma, and the final sections of that scene, in which soprano and chorus sing in elegantly crossing lines, gives some idea of the relationship between sindènan and gérongan.

25. In most gending, the words selected by a singer are semantically irrelevant. Formal considerations alone must be observed--the number of syllables to the line, and the vowel sound of each line's final syllable. Most gending use one of a very few types of verse, such as kinanti, kinanti jugag, sinom. The lyrics usually consist of, first, several disconnected phrases, which hint by their meaning at other words that appear in the later lines of the verse, usually in epigrams and little words of wisdom. For example, the first line of the standard verse of kinanti jugag reads, "Parabé Sang Marabangun" (the name for King Marabangun) which is Priyambada, and the third line reads, "aja dolan lan wong priya" (don't dally with men, although the language is somewhat archaic and so not so hideous as my rendering). The "priya" has already been foreshadowed by Priyambada. These wangsalan, as they are called, are very ingenious, but most singers know at most a few examples of each type of verse, which they use over and over for all gending.

The words are in no way intended to express or reflect any feeling. They are simply vehicles for the vocalists' lines. For that matter, they are usually unintelligible to Javanese listeners, since the singer often breaks a word in the middle. Gamelan insists that things fit together, not that they concentrate a mood. 
The striking characteristic of Javanese gamelan is, precisely, that its several musical lines do not have a single focus. The different instruments give great contrast in texture, made as they are of bronze, wood, bamboo and two types of strings, plus male and female vocalists. But their sounds do not combine harmonically, nor do they come forward and yield way in the shifting patterns of dominance characteristic of a Western orchestra. All 1 ines are important, but none, except the balungan, is indispensable. It is quite usual for a group of gamelan players to gather for an evening's practice without vocalists. And only rarely, in the brisk rhythm gending, does the balungan show itself clearly. Otherwise, it takes its piace in the profusion of sounds as rhythms two, three and four progressively expand the intervals between balungan notes. The various gongs provide signals to the phrases in the course of a single gongan (series of notes ending in the sounding of the large gong). A player can, if he gets lost, 1 isten for the kempul, kenong, or--if he's really lost--the gong, to reorient himself. A singer listens particularly carefully for the ketuk to shape each phrase. There is also a kind of hierarchy among the instruments to signal certain changes in sections of a gending, and from one gending to another: the rebab has priority in this matter; if there is no rebab, the gènder; if no gènder, the bonang barung.

The power that holds the ensemble together is the drum. A good Javanese drummer can achieve a great range of color and even pitch. While the variety of rhythmic patterns is large, the drum communicates the beat in a way that is sensible after remarkably little exposure. Most rhythm changes are gradual, and a few conventions, once known, make the drummer's guidance immediately understandable.

The structure of gending is basically circular. Each section consists of the repetition of a series of notes (the balungan) an indeterminate number of times. An accelerando means a change in wirama (roughly speaking, tempo) and often a shift from one section of the gending to another. Slackening tempo means a shift in wirama, or termination of the series of gending. There are four recognized wirama and further types of drumming implying special ways of playing (ciblonan, and bedayan, in addition to the standard kendang kalih (two drums] technique). Actually, while wirama are generally linked to tempo, they may also be thought of as gears: they determine the ratio of notes played in variations to the basic balungan notes. In wirama one, for example, the bonang barung plays two notes to one balungan note, but in wirama two he plays four to one. (And the bonang panerus plays two notes to each note on the bonang barung.) The moment of shift, from one wirama to another, is not set--when each player feels he can comfortably change, he does so. The point is to maintain a steady flow.

Volume does not vary greatly in Javanese gamelan. In wirama one, especially saron, gending are played loud; in the other wirama, more softly. In fact, it is difficult to imagine any way that volume could be further regulated, since no person in the ensemble has authority to influence "expression," except in so far as the drummer determines wirama, and wirama implies greater or lesser volume.

Nothing could be more unlike a Javanese drummer than a Western conductor. The Westerner signals--points, scowls, pleads for, demands --changes in expression, emphasis, tempo and so forth. The whole ensemble literally centers on him. His instructions are direct, visible and, in rehearsal, verbal. A Javanese drummer is more like an invisible presence. The way that a gamelan is set up in performance, a rectangle with parallel rows of instruments arranged so that each player 
faces forward (sléndro) or to one side (pélog), 26 with the drummer in the center, precludes the possibility of players observing their "leader." Nor, of course, would it do them any good. The drummer's influence is constant, yet subtle and somehow disembodied. The sound seems to come from nowhere and is never loud. Yet if listened for conscious$1 y$, it can always be discerned. It rarely need be 1 istened for consciously, for that matter, since only very rarely are shifts signalled by arbitrary cues, ones that must be recognized by the players. Instead, Javanese drumming carries the sound forward with gradual changes in tempo.

The aural unity of Javanese gamelan depends on a11 players observing certain, rather vague considerations of patet. Patet are subdivisions within the laras of sléndro and pélog. They are not scales-sléndro has one, pélog two quite resolutely five-tone scales-but rather patterns of stress and resolution within each of those scales. So in sléndro manyura, the final gong is usually 6 , and notes 1 and 5 are deemphasized. These latter are stressed in sléndro sanga, and 3 is scrupulously avoided in positions that receive stress (that is, the nodal points marked off by the various gongs). Patet are comparable, I am told, to the modes once important in Western music.

Rhythmically, unity depends on the principle that the deeper an instrument's range, the more rarely is it sounded: so the great gong is struck only at the end of each section, while the smallest saron, bonang panerus and gènder panerus play light and speedy ornamentation in the highest registers. The rhythmic integration of gamelan permits instruments to associate with the intimacy of interlocking imbal parts or at the discrete intervals of the gongs. They never come together in the fused harmonies of Western music, however. To achieve specific harmonic combinations between instruments would require limitations on each player's freedom of action quite foreign to the principles of gamelan. Nor do the scales permit the proximity of half-tones (as Sundanese gamelan does).27 A certain discretion is maintained at a11 times. Aside from patet, the many lines and variations in Javanese gamelan meet in the single notes, or nodal points, which they all sound together. Between these meetings they go their separate, although parallel ways. Finally, all submit to the subtle power of the drum and by that accord assure their--the word in the West is harmonious, but for Java it is consonant--interaction.

My point is that the players in a gamelan must submit to the organizing principles of balungan, drum beat and pațet in order to work

26. The parallel lines resemble the preferred pattern for houses and paths in Javanese villages. As far as space permits, Javanese villagers build houses and fences in their lots according to straight lines roughly congruent with the cardinal directions. This makes possible the habit in speech--connected to the general stress on physical orientation in space--of using compass directions rather than right and left. So a person says of a radio facing south, "Do you turn this knob east or west to turn it on?"

27. There are two exceptions to this rule. The rebab, and less frequently, a pesindèn, can begin a phrase with a sliding approach through intermediate tones to the main note, and the unexpected effect is very striking. In a very few gending, too, the rebab and pesindèn deliberately sing very slightly off-key. These very beautiful gending, played in wayang kulit and wayang wong on the death of a hero, use this technique to convey the sadness of the moment, and so are exceptional also in the explicit evocation of emotion. 
together. But those "rules" still give each player a remarkable freedom of action to select variations (kembangan, from kembang, ngoko for flower) as he goes. Gamelan is conservative: many variations, like conversation, are standardized. But every player can make up, borrow or modify, and in any case must select, variations as he goes. The aural richness of Javanese gamelan--uniike Balinese gamelan--depends on the weaving together of several very distinctive kinds of sound. But the weave, or really several weaves, which are the several wirama, are very loose. The drummer, like the ideal prince, exerts considerable influence by a subtle power. But at a point much sooner than in Western music, each player is on his own. There are given rhythms in music and given styles in encounter. But underlying them all is the notion that each individual has a certain sphere of action which is exclusive1y his own. When Javanese speak of music or interaction, the words that constantly reappear are cocog (to fit, to go together well, to jive), kepénak (agreeable, pleasing) and rasa (feeling). Agreeableness hardly strikes Westerners as a significant aim in either society or music. And yet the flexibility of Javanese interaction and the beauty of gamelan depend on just that: the ability of individuals to interact in such a way that they cocog, that they fit together like surfaces of various but complementary textures.

A Westerner who hears Javanese gamelan for the first time may find it unfocused and directionless. Javanese interaction seems to have the same thin consistency on first encounter. But if an outsider concentrates his attention on what is, in fact, the focus of Javanese attention, the field between I and you, then he can appreciate the play of quite other elements to encounter. The oppositions and guide lines I mentioned earlier give face-to-face interaction a consistency of its own in Java, quite unrelated to the society's corporate vagueness. The Javanese language, with its expressiveness of both social form and sensory experience, gives texture where Westerners see only flat surfaces. Javanese conversation fails to meet Western demands for originality, focus and dynamics. Westerners' conversation and action fail dismally to provide the Javanese with any sense of style, sensitivity or flexibility. Javanese interaction, like its music, aims for an effortless but measured meeting of people in greater or lesser intimacy, expressed through various types of contrast, but which leaves every person a discrete field of action. The ideal is not to avoid touch but to avoid knocking heads. It is, precisely, because of this social discretion, I think, that touch is so much more possible in Java among members of the same sex than in America. In America, touch is quite unequivocally expressive of sex. In Java, it is when the deeper implications of sex are present that touch becomes more delicate. And it is this discretion that makes it possible for Javanese to live together with their relatives more--I will not say happily, but certainly peacefully--than Americans can.

Yet it is true that the subtly directed action of distinct members of a group discreetly linked which motivates gamelan has little counterpart in Javanese society today. Villagers do not trust each other far enough to engage in cooperatives, and petty officials who impose cooperatives all too often prove unworthy of the "trust" they extract. The distension of what fiber there was in Java has occurred at a11 levels. The sultanate that fifty years ago cultivated wayang wong to become a truly great art form, and that as much by the total devotion it received from the players as by financial support, now hardly observes what little activity it can still make possible. (The distension of the sultanate's political muscle occurred, of course, long ago.) The corruption of officials is condemned but assumed and so in 
a sense dismissed. Nor has any type of pressure so far been found, or exercised, to counteract this pervasive tendency to bocor, to spring a leak like a bicycle tire. Certainly, much of all this derives from Java's terrible poverty. And the Dutch presence no doubt had a destructive effect on any corporate unity Java had in the past. But where does Java go from here?

Java is undergoing an organizational floundering which--in view of its awful demographic pressure--is unspeakably tragic. Yet in one to one interaction, the chaos outside never impinges on behavior within the fully given range of expression between $I$ and you. One thing Java does not permit is a sense of panicked urgency in action. Whether looking for a doctor for the sick, or implementing the current family planning program, a deliberate, but one can only feel, inappropriate, calm prevails. So like two people who sit down to play gamelan, a considerable measure of accord and satisfaction can be achieved in Javanese interaction. But the fact remains that the link is purely one to one, and further expansion is difficult when, as is certainly the case in Javanese society today, there is a serious lack of drummers.

\section{$\underline{B a 1 i}^{28}$}

Bali considers herself Java's cultural offspring in much the same way that France terms herself la filze ainée de l'Eglise. Bali's language, art and literature owe much to Javanese traditions and Balinese trace their ancestry to the Javanese nobles and religious leaders who brought civilization to the island's indigenous inhabitants. After a fashion, though, Java has become Islamic, while the Balinese maintain the religion they believe to have been brought them by the Javanese. So the Balinese tend to see their culture as the flourishing progeny of a now senile parent.

To live in Bali after a time in Java gives rise to a frequent sense of recognition--pada waé the Javanese would happily say, "It's all the same." But there are aspects of Bali that are astounding after Java: the remarkable absence of petty thievery, the vigorous village organizations and the general sense of strong social bonds. Geertz has described the difference in the economic sphere in Peddlers and Princes. 29 Here I would 1 ike to point out various other indicators to Bali's remarkable social plasticity and try to show, if not why, at least how this capacity to form viable--if momentary--social groups contrasts to Java's strictly one to one action. I believe the similarities stem from like patterns to interpersonal action, while the differences depend largely on a peculiarly Balinese notion of groups. I will begin, again, from language, since Balinese is organized in levels as in Javanese but these levels fit the set divisions of Balinese society into caste. I think the tendency to categorize, or actually just divide up, society runs through many other aspects of Balinese culture. Individual experience can be dealt with in terms of categories and interlocking sets. And the groups which distinguish Balinese village 1 ife by their variety and energy reflect the same

28. I lived in a village in the area of Tabanan for seven months, and another village in Gianyar for three months, in 1973. I was only able to study Balinese gamelan in Gianyar and so I speak of it from much less experience than in the case of Javanese gamelan, which I studied for eighteen months.

29. (Chicago: University of Chicago Press, 1963). 
tendency to group, combine and recombine. These sekaa make disciplined interaction in groups possible despite motions about the limits to interaction very similar to Java's. I will conclude by comparing Javanese and Balinese gamelan in terms of their organization.

$\underline{\text { Language }}$

The Balinese language is characterized by speech levels elaborated in much the same way as in Javanese. There are the main categories of high and low (termed alus and biasa, alus and omong Bali, or, more correctly, alus and sor), plus the special vocabularies of high respect to second and third persons (basa singgih) and humility for the self and low status third persons (basa ipun). There also exists a vulgar vocabulary, terms of insulting crudity. Relative to Javanese, Balinese lacks only a specifically madya vocabulary. But the kind of sound changes, and intonation patterns Javanese has are not so developed. (One example: the suffixed - $e$ and -ipun in Javanese have only one form, -é, in Balinese.) In fact, the marked items of Balinese vocabulary number far fewer than in Javanese. Many people tend to think of basa alus as Javanese-derived, basa sor as indigenous $1 y$ Balinese. I don't think examination of the vocabularies bears out that generalization, except, perhaps, for the honorifics of basa singgih. Instead, Balinese Javanese and Indonesian seem to play leap-frog. Items now relegated to 0ld Javanese in Java are part of everyday Balinese; what is alus in Java is kasar in Bali and the reverse; and very often, a word used in Indonesian appears in low Balinese, while the singgih term in Balinese is the same as the Javanese ngoko form. ${ }^{30}$

The selection of speech level depends on relative status, but the determination of status is quite simple. Status depends on caste. The caste system consists of four main groups: pra Brahmana, pra Déwa, pra Gusti, these three termed collectively anak ménak, nobles; and the vast majority of Balinese, anak jaba (1iterally, people outside, that is, outside the aristocratic compounds). There are several further subdivisions, but the only one of great significance in matters of speech is the pra Dewa and pra Gusti, who are of royal 1 ineage. The rules are basically that a person can speak low Balinese among members of his own caste and inferior ones, while he must use high Balinese, plus basa singgih and basa ipun to members of higher castes. In situations in which low Bainese is being used, reference to a high status third person still requires the use of basa singgih. (This rule is followed much more strictly than in Java, where only the very highest members of the aristocracy are consistently referred to in krama inggil by villagers.)

In theory, at least, the issue of formality versus intimacy is not involved. Nor are wealth and education. In practice, things are not quite so simple, particularly between strangers. But to consider first the speech patterns of people living close enough to know each other by name and therefore caste: here the rules apply quite consistently. In

30. Covarrubias's statement in Island of Bali (New York: Knopf, 1950), that the levels of Balinese constitute unrelated languages is quite wrong. There is a curious tendency for verbs to have different prefixes and suffixes in high and low Balinese, but in fact there is also great regional variation in the use of verbal affixes in Bali. Between levels, syntax and idiomatic usages correspond precisely. J. Kersten, Tata Bahasa Bali (Ende-Flores: Pertjetakan Arnoldus, [1970]), gives a thorough discussion of Balinese speech levels. 
the area of Tabanan where I lived, at least, there was not a very high rate of in and out migration, other than the newly married women who move into their husbands' compounds. So within a fairly broad area (the range of course depending on the density of the population), everyone is known at least slightly and so by caste. In the case of children, one need only ask whose child a young person is, and the issue of caste is settled. Within this area, anak jaba will speak to each other in low Balinese without further regard to considerations of status, wealth, age, or familiarity. School children may use a few key words of alus in speaking with non-kin elders. By the time they stop school, however, they cease doing so. In fact, within this area near home, encounter is marked by a kind of generalized familiarity which may not imply close friendship but is still wonderfully relaxed and easy. Among people of the same area but different caste, the lower caste speaker often uses a mixture of high and low. Alus high frequency words are used as signs that one is speaking alus even though many other items are in biasa. Young people often speak almost entirely in low Balinese, making sure only to use tiang for the first person singular rather than the lower form, icang, plus the specifically caste-linked terms of direct address and a few other words such as those for the houses of members of different castes. Even older people will use a strictly alus vocabulary only for the honorific terms directly touching on the second person. The only instances, at least in the area of Tabanan, in which people consistently speak fully alus are in speaking to an Ida Peranda (priest from the Brahmana caste) or one of his relatives, and with persons of royal lineage. Only here, too, is there much attention to stylized gesture: seeking low places to sit, starting a conversation with the respectful sugra and accompanying gesture, and so on. These are reminiscent of Central Java's krama gestures, but appear much more rarely. For the rest, it is sufficient to make clear that one recognizes the difference in status.

To equate this manner of speech with Javanese madya, however, would mean overlooking the fact that at least in this area near home no implications of status are expressed aside from difference in caste. To a limited extent, familiarity affects speech patterns, in that one may use a bit more alus in speaking to an anak ménak from another hamlet than with those living in one's own hamlet. But the difference is not great. Status has only one dimension, caste, itself a given set of categories. So the fine gradations of Javanese are irrelevant to Balinese encounter.

Outside the area in which people are personally known, speech levels present a problem in Bali that does not occur in Java. A person's caste cannot, of course, be guessed. There is a stereotyped question with which to ask (Titiang nunasan antuk linggih, I request your station), phrased in basa alus with basa singgih and ipun. The person asked replied either by stating his caste (Titiang soroh Déwa, I am of the group Dewa) or by giving his title and name (Wastan tiang I Déwa Ketut Rai) if he does not yet have or use a teknonym. The first person then usually indicates his own caste. The formula is very common but I believe there is a certain reluctance among young people to use it. Caste distinctions are undemocratic, in this view, and so rather embarrassing to talk about openly--although all considerations of caste remain fully operative. In any case, one senses a certain awkwardness when the stream of conversation is interrupted to put the formulaic question. And in brief encounters it would be impractical to inquire into caste at every turn. So several patterns arise. First, in the impersonal encounter of shopkeeper with customer, or people in the street, there is a tendency among educated people to use 
Indonesian, since it has no speech levels. In the market, on buses and so on, people usually speak, again, a mixture of Balinese, with high frequency words in alus and most others in biasa. Un1ike the madya spoken in the Javanese market, though, which is used because it is appropriate among unfamiliar, low-status speakers, this mixture is used because it is safe--not offensive to the other person should it turn out he is an anak ménak. In other, more personal encounters, even if it becomes clear that both speakers are anak jaba, the conversation may remain in this mixture for a time. How long it takes two speakers to shift to low Balinese, whether in the first meeting, after several subsequent ones, or ever, depends largely on the personalities of the two speakers. 31

But in Tabanan, at least, this is a new development. The head of the family with whom I stayed, a man in his fifties, said that when he was younger as soon as it was apparent that two speakers were anak jaba, they shifted to low Balinese. One can easily imagine a stiffening of formality in Balinese society, as there is steadily more frequent contact between strangers. Encounter also seems to be more difficult, or at least more formal, among educated people than among villagers. Education, wealth and high status often go hand in hand in the towns. A friend told me that, when in town, it's a good idea to call any anak menak who works in an office Ratu (the term of direct address used to pra Brahmana and others of royal descent): the chances are, if he's got such a good job, he is of that ilk.32 In the towns, even when education and wealth are not 1 inked to high status, they tend to imply a preference for using basa alus with other educated people. In other words, there is some shift of emphasis in the use of speech levels between village and town. The vaguer criteria of relative wealth and education do enter into consideration in the towns.

Despite this tendency in the towns, one senses a much less meticulous attention to the social implications of language in Bali. In Java, the minute a speaker injects a word of madya into his previously pure krama speech, it carries a message. It could be called "socially audible." In Bali, no such intense attention applies to the use of marked vocabulary. In fact, it is much less strongly marked, as we 11 as much less highly elaborated, than in Java. The predominant consideration is caste, and provided difference of caste is observed--even if somewhat perfunctorily--then social form has been fulfilled. 33

31. Also, on their surroundings. If they should meet among a group of friends all using low Balinese, they are likely to shift quickly. This is hardly the case in Java.

32. While the Balinese system of caste does not have the political implications of Western noble classes, nor really the implications of social status per se, nevertheless it is my impression that a disproportionate percentage of the white-collar jobs to be had in Bali are held by anak ménak.

33. The Balinese often say, "I don't know how to speak alus." The Javanese say the same but in Bali it has more basis in fact. If someone happens to grow up in a hamlet in which there are few anak ménak, he will hear alus speech relatively rarely. He will, of course, know the high frequency words but probably not all of the special sets singgih and ipun, nor even some words of undifferentiated alus--at least not actively. This is certainly the case in Tabanan. I am told that speaking alus is a more highly practiced skill in eastern Bali--while in Singaraja, nobody knows how to speak it properly. 
The above comments apply to Balinese as it is used in everyday exchange. Literary Balinese, Old Javanese and Sanskrit also figure in ritual and theatrical situations in Bali. Sanskrit pertains exclusive$1 y$ to the Ida Peranda, in the mantra (incantations) he pronounces at the crucial points in the rituals he performs. It is totally esoteric. Other religious situations require old Javanese, used by both the Ida Peranda and the mangku (religious officials responsible for temples) when they recite invocations. When women set out offerings around the house and yard or perform any of their other everyday ritual duties, they use flowery Balinese pronounced in a long, rising intonation pattern peculiar to these situations. In gatherings for the reading of kekawin (epic verse), held either for ritual purposes or for the fun of it, one person sings a line of the 01d Javanese text, while another person $m / b a s a n i n$ (renders into contemporary--if florid--Balinese). In performances of wayang, this same pattern of 01d Javanese and Balinese occurs. The main characters, whether good or evil, speak in old Javanese (its purity depending, of course, on the dalang's knowledge of old Javanese) while their servants masanin. Dramatically, there is an evident problem, since the action is considerably slowed. But the device is needed because only a few old men can understand old Javanese well. And it would strike the Balinese as incongruous for wayang figures to speak contemporary Balinese. The subtle differentiation of voice and language which are the crux of a Javanese dalang's skill are much less developed in Bali (whereas old Javanese has all but disappeared in Java). Instead, there is a single distinction in performance, between the remote, old Javanese-speaking classical characters, and the hilarious and immediately understandable servants. 34

The aspect of 1 inguistic usage which I would like to stress is the existence of simple ways to classify situations, and people, and so determine language. Among human beings, it is caste, and to a lesser extent, familiarity. In religious situations, it is degree of ritual importance. The most significant rituals require Sanskrit and old Javanese mantra pronounced by the Ida Peranda. The regular cycle of temple and shrine ceremonies requires old Javanese. The daily dedication of offerings requires alus Balinese pronounced as a sort of incantation. In wayang, the opposition of classical figure--whether

ksatriya or giant--to comic servant distinguishes between the use of Old Javanese and Balinese.

34. Wayang provides an interesting point of comparison between Java and Bali. Paradoxically, wayang is both more truly alive in Bali and more distant and indistinct. After all, Batara Guru, who rules in the heaven of wayang, al so melinggih (resides) at the kamulan shrine of each household. Yet he has no discernible character, unless his Javanese counterpart, no more than most figures in Balinese wayang. In Central Java, over a hundred figures are immediately recognized and describable by a twelve-year-old villager. In Bali, wayang come in for the same respectful distance that all the other gods, ancestral spirits and demons receive.

The point was brought home one day, on the odalan of Saraswati, the goddess of learning, when I asked whether Saraswati was male or female. Neither the children out of school for the day--one may neither read nor write on the day, out of respect for Saraswati--nor the woman putting banten (offerings) on my books at that moment could answer. "It ends in $-\underline{i}$, so probably female," was the conclusion. But they suggested--all discussions of religious matters end this way--that I go ask the Ida Peranda. 
Categorizing the World

The Balinese have, in fact, a veritable passion for setting up categories, dividing things up, grouping them this way and grouping them that. My purpose here is not to consider the specific content of any one instance of this bent, but to give an idea of what an abundance of slots, oppositions and rules give Bali its peculiar shape. Geertz has described the calendrical and naming systems. ${ }^{35}$ There are also numerous ritual cycles, vast and divisible into five types: déwayadnya (for the gods, as in temple ceremonies); pitrayadnya (for the ancestral spirits, most notably the series of rituals surrounding creation); manusayadnya (for human beings, the cycle of rites of passage, of which tooth-filing is the largest within a person's lifetime); butayadnya (for the spirits of the earth and those in particular places, whose favor must be curried with special offerings, especially in the event of misfortune); and finally, resiyadnya (for religious officials, involving matters of ritual purity). Each ritual within each group requires a pertinent number of ritual offerings made out of intricately fashioned leaves, flowers and sweets. Each offering, in turn, is made up of a pertinent number of constituent parts. Particular points in ritual require verses to be sung from the religious poem appropriate to the category of yadnya involved, and each category of ritual requites different gending to be played in gamelan.

As Jane Belo has written, the cardinal directions, mountain and sea, upstream and downstream, high and low, right and left, are all marked in Bali. ${ }^{36}$ (Paling covers the same range of emotions as the Javanese bingung, but in fact $I$ think is even more unsettling to the Balinese.) Many of the considerations Belo describes no longer receive such strict attention. Public transport, for example, does not allow for much concern with the relative height of the head. Still, the rules are there. Once a friend came into my room just after I had changed clothes. He pointed out that trousers, and especially underwear, should be placed at the lower (called downstream) end of the bed, while shirts, if put on hooks, should not be hung too high. Nothing should be above, on or near the pillow. The head of the bed must be placed in the "high" north or east and is called "upstream."

The arrangement of a Balinese yard also indicates the way space is marked out. Every nuclear family (or at least, families in direct line of descent: great-grandparents, grandparents, parents and children) should have a set of constituent balé (building, construction): the balé kaja ( $k a j a=$ north, or toward the mountain) or balé gedong (gedong = building made of plaster, bricks and tile, rather than the traditional materials of wood and thatching); bale Bali (made with traditional materials and according to specifications determined by caste); paon (kitchen or hearth); and rice granary; plus, for ritual purposes, a pelinggih kamulan, taksu kamulan and if possible, tugu. The pelinggih kamulan and taksu kamulan, shrines for ancestral spirits not yet through the cremation cycle, are placed in the furthest northeast cor ner, the first facing west, the second south. The bale kaja, with enclosed sleeping quarters and an open platform for receiving guests, is in the northern area of the yard. The balé Bali is south of the balé kaja. It is here that a person in his death agonies is laid, and here that the body is left until burial or creation. (If a person dies

35. Person, Time and Conduct: An Essay in Cultural Analysis (New Haven: Yale University Southeast Asia Studies Monograph Series, 1966).

36. Traditional Balinese Culture (New York: Columbia University Press, 1970). 
anywhere else, offerings must be taken to the spot to convince the spirit to come home--to the balé Bali.) The kitchen is usually south of the balé Bali, and the rice granary either south or west of it. If there is a pig pen, it must be furthest south or west, these being the least pure directions.

Nuclear families usually live in a pemesuan (a walled compound) along with one or several other families of agnatic kin. So the pattern described above is repeated several times in a row, stretching east to west. At the easternmost point there is another shrine, the tugu penunggu karang, a shrine for the spirit that guards the yard, one for the entire pemesuan. Then there is a sanggah gedé for anak jaba (for anak menak, it is called a merajan), a clan temple situated at the northeastern or northwestern corner of one or several agnatically-

1 inked pemesuan, in any case adjacent to the largest path passing them. Finally, the hamlet or village has a pura puseh (usually at the north) and pura dalem (usually in the south, in any case, next to the cemetery), which are temples for all inhabitants of the village.

It all sounds very orderly. In a sense--the rules--it is, particularly in the way that every level of "corporateness" from nuclear family to agnatic kinsmen to village (and in other contexts, agricultural organization, ancestral origin and so forth) is marked off by a religious shrine. But to look at a Balinese village, you'd hardly say so. Spacing is highly irregular, and there is a tendency to put different balé very close to each other. No effort is made to set balé up in a line. Everything is askew. The result is not orderly but a great clutter. 37 Nor do people of higher caste feel that they must distinguish themselves physically from their lower caste neighbors. Often the walls "around" a pemesuan exist only in front, near the path, so that passing through the gate is like going through the false front on the set for a Western. As in speech, arranging a houseyard in Bali is governed by very clear lines which get a little obscured in practice. But the point is not to fix order: the order is there, and so one follows it more or less precisely. The fences around a Javanese yard, and the social pertinence that marks so many words in Javanese, impose order on relationships that have no consistency apart from those markers. A fence does not reflect a category of kin, in Java, and speech levels reflect only vague differentials in status. The fence marks off ownership, and speech levels set the relationship between speakers. In Bali, on the other hand, vocabulary sets, religious shrines and fences a11 reflect clear divisions in society.

The Balinese taste for ordering and connecting things comes out in all its exuberance in the lontar literature of tutur. They contain information on all ritual matters, on methods of curing, on the origins of religion, people, trees, and so forth. A striking aspect of tutur is that the word text hardiy seems to apply, at least if one wants to speak of "the integrity of the text." A particular set of lontar leaves may appear to have a beginning--an opening series of mantra and magic symbols, and even some explanation as to the context of what follows--but no end. Rather it breaks off quite suddenly, or, more often, trails off in a series of increasingly disconnected and sometimes repetitious or contradictory fragments. Tutur often seem a collection of

37. The Javanese always come back from Bali clucking at what a mess the place is. The Balinese come back from Central Java saying, "They're alus--but lazy." Central Javanese and Balinese all come back from East Java saying, "They're keras." 
notes, a shorthand for--truth. I use the word "truth," though it is not a word with any equivalent in Balinese or old Javanese and so is perhaps inappropriate. But one feels in reading a tutur, with its strings of potent letters, the connecting in great streams of gods, organs, demons, directions, colors, numbers, days, flowers, and numerous other elements of reality, and their collapsing combinations and reelaborations, that one faces not a particular account of a particular subject, but one. opening onto a single sea of esoteric knowledge. The integrity of the text does not lie in the organization of material within its particular limits, but precisely in its lack of 1 imits. Its unity depends on the single method of processing reality, no matter what the subject at hand-- by distinguishing, naming, categorizing and connecting, everything to everything. In the case of the human body, one finally gets the impression of a great sackful of movable parts.

\section{Applying Categories}

So far I have described systems in which fixed elements--categories of space, the houseyard, anything that falls into the lontar's mystical grasp--are systematized. The question remains as to whether the Balinese actually apply these categories to their experience, that is, whether given forms can rea11y affect the way people think about what happens to them, and whether the pattern of distinguishing and linking categories in the field of esoterica appears as well in the way people get along with each other. To begin with the way in which tutur connect directly to experience in Bali: they provide one stream of Balinese curers, balian wisada (curers whose practice depends on the use of lontar texts) the materials with which to treat sickness. Any one person's birth is the point of conjunction of many interlocking calendrical systems. This conjunction indicates--a balian has only to look up in one of the great catalogue wisada texts--the person's character, misfortunes and boons in life, talents, failings and, most importantly, sicknesses. For each sickness, the text enumerates the many offerings required. Sickness can usually be described by symptoms: panes (hot), anget (warm), tis (cool), nyem (cold in the way a person feels having stayed too long in water), and dumazadi (all of the above, in balance), in different parts of the body. Often one illness is caused by conflicting conditions in different parts of the body (legs nyem but stomach panes, for example), these in turn caused by the physical environment, foods, exertion, and so on. Both offerings and herbal medicines enter into the cure as directed by the texts.

Physical sickness is not the only aspect of an individual's experence that can be linked to the date of his birth. Characteristics which we call personal or psychological are also linked to the conjunction of calendrical sets. For example: one day when I went to visit a balian èngèngan (a curer whose practice stems from his ability to act as medium for the gods, ancestral spirits and demons), a man was there to ask about his fifteen-year-old son's persistent misbehavior. Always given to cutting up, the son had, just one week previously, wrecked an armoire. The balian did not even have to use his medial powers to discern the cause. He explained that since the boy was born on a Saturday, the god that had authorized his birth was Betari Durga. Betari Durga is the malevolent, or at least volatile, wife of Betara Guru, who resides at the pura dalem. It is usual for children born on Saturday to misbehave. The remedy lay in the offering of banten panebusin (banten = offerings, nebusin = to reclaim by paying a sum) to Betari Durga. The nature of such banten, particularly the number of constituent parts, depends on the urip, the number mystically associ- 
ated with Saturday. These offerings are usually made at a child's third otonan (the recurrence of the original configuration of week [wuku], seven-day cycle, and five-day cycle on which a person was born).38 But subsequent behavior may indicate that the banten were not accepted and so they must be proffered again. It is telling that, far from being seen as "patron saints," the gods associated with birthdays are seen as something like creditors to be paid off quickly. More generally, it is apparent that the clichés of Western psychology have little pertinence to the Balinese view. The boy did not get so rowdy-his personality was not shaped--by the cumulative effect of experience. Nor were his ways to be changed now by parental action. Instead, the sets and correspondences connected by the time of his birth accounted for his behavior, and indicated what was to be done.

The Balinese do not discount all links between what happens to a person and what he is like. An only child, they say, will get: to be a spoiled brat because he never has to give way to a younger sibling. But they do not think that every "self" represents a particular subjective distillation of past experience, and they do not stress family iffe as the major source of personal make-up. In this case, the boy's "problems" were not with his parents. It was just something between him and Betari Durga. It could happen to anybody--born on a Saturday.

The approaches to sickness and character discussed above concern ways to handle an individual's experience. Interaction and group effort, I think, show a similar pattern of combining people in sets. For one thing, the way that speech levels operate reflects the categorization of people into caste. Speech does not implicate the nature of a relationship, the feelings between two people, in Bali as much as in Java. In villages, people of differing status may be the closest of friends, even though one must use some measure of alus in his speech. This is hardly possible in Java, where krama implies a type of relationship, not just a form of speech. 39

I think the Balinese penchant for handling elements of reality as members of sets provides a useful way of looking at a side of Balinese society which, after Java, can only inspire awe--sekaa. Geertz has described these eclectic organizations in his article on Balinese village organization, "Form and Variation in Balinese Village Structure."40 Like Flanders and Swann's wompom, there is nothing that a sekaa cannot do. Or more accurately, there is nothing that Balinese cannot do as a sekaa. Here are just some of the sekaa that operated in the hamlet of thirty-two families in which I lived: the harvesting sekaa (one person

38. A wuku consists of seven days, and there are thirty wuku, so $7 \times 30=210$ days to the wuku cycle. And since 210 can be divided evenly by 35 (the product of seven and five, the two pertinent day cycles), the wuku, seven-day cycle and five-day cycle always agree--that is, Saturday in a particular wuku will always fall on the same day in the five-day cycle.

39. One evening $I$ was at the puri of a family of pra Gusti of royal descent when the driver for a foreign couple staying there at the time went off to sleep with our host's teen-aged sons. The driver was an anak jaba who had only met these grandchildren of kings a couple of days before. The difference in status was on the order of an abyss, but it did not seem to matter. In Java, the driver would have slept in the back with the servants. (I am told, however, that in other areas of Bali, caste differences instill greater social distance.)

40. In American Anthropologist, LXI, No. 4 (1959), pp. 991-1012. 
per nuclear family); the squirrel-hunting sekaa (one person per nuclear family); the copra sekaa (eight members); the tape recorder sekaa (eleven members who put up the capital to buy a tape recorder and loud speaker); the banten-making sekaa (one woman per nuclear family); and the rice-huller sekaa (thirty-two members). Every sekaa has its own rules and meets only when the need arises. Membership in some is a privilege granted in periodic meetings (as in the copra sekaa); in others, a responsibility that every nuclear family must fulfill (one body per hearth, as in the harvesting sekaa--since it does not matter which body, its participants change from day to day), although participation always implies some form of remuneration; in still others purely voluntary and open to all (special project groups like the rice-huller sekaa and the tape-recorder sekaa). Any one person takes part in any number of sekaa, as well as doing the types of work (like weeding) not done in sekaa.

Even when no sekaa are involved, work in Bali tends to take on the character of an open house. Within one or more banjar (hamlet, communal work may be classed ngayah or ngopin. Ngayah is compulsory banjar or village-wide labor done for public improvements, such as road repairs or the collection of coconuts for the banjar's coconut tax. Failure to work brings a fine (penyalah) of (currently) fifty rupiah a day, about the price of one meal of rice and pork in Balinese villages. A person who holds a full-time job may pay a fee periodically to be excused from all village labor. Often, as in preparations for some rituals, fewer hands are needed. For this reason, the banjar is divided into smaller sections, kecik. Where I lived, the hearths that had to provide labor numbered twenty-four and these were divided into three kecik. Failure to attend kecik labor brought a very small fine. The fine's purpose, I was told, was "just so you notice who didn't come." If a family is receiving help from kecik, they must pay a small sum to the banjar treasury, and provide meals for all the people who come. Actually, for most household projects, ritual preparations or housebuilding, for example, people ngopin, work voluntarily. They receive in exchange food and the assurance of help in return when they have need of labor at home.

People take penyalah very seriously. All fines must be paid up at the time of the village meeting, held irregularly, every year or so. Three days after that meeting, outstanding penyalah double automatically. Shortly thereafter, if the delinquent still has not paid, the kelihan banjar (banjar headman, an elected post) simply goes and auctions off whatever of the householder's possessions it takes to raise the sum. The same pattern applies to debts to the warung (place for snacks, a concession contracted out at two- or three-year intervals, with either a flat sum or a percentage of the profits going to the banjar treasury) and to interest on loans from the treasury. But the last time anyone in the banjar where I lived could remember things going so far as an auction was a case of debts to the warung, fourteen years previously. Group pressure is very, very real in Balinese villages. A young man once mentioned to me that there was a woman in the banjar who had had the habit of stealing from other people's gardens. When this came to public attention, a meeting was called and the woman was informed she should stop. If she did not, the next time she was caught she would be killed.

The habit of ny/sekaa (an active verb meaning to do as a group, or to share--a mother tells her children to nyekaa a handful of crackers) makes it possible to extend trust to fellow members of one's banjar, or beyond, in financial matters. A striking example was the 
rice-huller bought by thirty-two members of the banjar where I lived. The idea started when someone said one evening, "Imagine what it'd be like to have a rice-huller right here." A month 1ater, the rice-huller was bought and in operation. The original cost for the machine and materials for the building the villagers constructed ran to about Rp. 450,000, towards which every member had paid (when I left six months later) Rp. 11,000. The organization allowed fifteen percent of the profits as wages to two operators, plus five percent divided up among the several penguru (overseer). But while wages were paid, dividends were given out only once in the first seven months, then "just to see how things were going." The point was not to make profits personally, I was told. Instead, any profits made after payment of the debt would go to village improvements. The rice-huller itself, people would say, was the "profit," since now villagers did not have to carry their grain such distances up and down bad paths.

\section{Cooperative Work and Interpersonal Encounter}

Anyone who has heard about the endless hassles attendant on "village" projects--usually imposed from above--in Java, can only marvel at such smooth-working cooperation. The contrast is so absolute that it would hardly seem meaningful to compare the two situations. But on another level Java and Bali are not only comparable but remarkably similar: at the level of face to face encounter.

The oppositions alus to kasar, formal to familiar and high status to low all exist in $\mathrm{Bali}$, although they generally receive less intense attention in matters of speech and behavior than in Java. And the Balinese show the same reluctance to impinge on others, the same avoidance of confrontation, the same insistence on achieving some feeling of common agreement, at least outwardly, in any encounter. In effect, they hold the same views about interaction which form the common core to ngoko and krama relationships in Java. The vocabulary for emotional states in Javanese can be translated one to one into Balinese with remarkably little distortion. In particular, the phrases which describe the overstepping of bounds-isin in Java, iek in Bali (in Indonesian, malu, shamed or embarrassed 4 ); ora wani Javanese, sing juari Balinese (ndak berani Indonesian, not to have the nerve); and lara atiné Javanese, gedeg basangé Balinese (sakit hati Indonesian, put out, incensed) --convey similar types of reactions to similar types of situations. As in Java, outright reference to the features of a person's head is in itself insulting--to say angrily, in ngoko or in low Balinese, "Your mouth!" or "You eye!" carries a wallop quite equal to any rough English epithet. As in Java, touching any part of a person's head or reaching above him requires saying a polite phrase in Bali (nuwun sèwu krama, amit ngoko, in Javanese; sugra basa ipun and tabik basa sor in Balinese). Touch, while easier in Bali than in Java, carries the same parallels to speech and implications as to intimacy. With an exception which I will explain later, direct criticism is just as difficult in Bali as in Java. Yet in Java, no groups function smoothly, while in Bali they fill up every inch of Bali's rococo social surface.

41. Geertz's rendering of $1 \mathrm{ek}$ as stage fright is certainly intriguing. But I must say his description of Balinese formality in behavior, the stylized regularity of face to face encounter, makes me think more of Javanese city-dwellers than Balinese. And in any case, it leaves out the dimension of kasar, of familiar relationships which, while still implying limits, hardly fit his description of elegant facelessness. 
I think the key to Bali's successful integration of a notion of social "discretion" in encounter with close cooperative work in groups lies in the nature of sekaa's organizing principles. As Geertz has pointed out, sekaa are actually very strictly limited, single-purpose organizations that cut along many different social lines. He calls the result a sort of "pluralistic collectivism," and stresses the resultant resistance an individual gains to conflicting village political pressures. I think it assures not only political "sovereignty" but what could be called the personal sovereignty Balinese (and Javanese) assume in social interaction. Equality is the rule. In a profit-making enterprise, all profits are shared equally, even when the organization needs to delegate a "chairman's" authority to one member. In a sekaa of performers, everyone receives the same fee. So in Bali's most famous arja groups (a popular entertainment, with singing, dancing and comedy), the clowns, whose names are known throughout Bali, receive precisely the same sum as the condong, players to whom hardly anyone pays any attention. Membership in a sekaa implies responsibilities, rights and rewards uniformly distributed. So there is 1ittle formal recognition of personal traits, of status, or even of differences in effort. One or two people tend to have the most ideas and take charge of what needs deciding, but since sekaa are so single-purposed, this does not usually cause too much tension. 42 For that matter, difference of opinion can be expressed within the confines of meetings, and people may even show a fair degree of anger in the process. But it should be phrased to show that one has the interests of the group at heart, not self-interest. That is, the elasticity and strength of sekaa as a social habit--institution sounds absurd applied to something so wonderfully plastic--makes possible the kind of expression close to impossible in other, one to one situations. 01d personal antagonisms do often underlie arguments in meetings. But it is difficult to imagine such vocal expression of hostility in any except the most unusual circumstances of personal, that is, non-sekaa, interaction. The presence of a group of people, at the same time, works ultimately to smooth over any rifts.

Comparison of sekaa to Western business organizations is the kind of comparison across realms that yields elegant intellectual nothings. But notice: Westerners assume a hierarchy of merit; a person intends to rise by shining; he is expected to offer allegiance to the company; and not just a vast amount of his time, but also of his status, his personal image, and even his feelings, are intimately bound up with his work. This is not so in Bali, where any one sekaa, aside from the "sekaa" of village residence (it is so deemed), is liable to take up only small amounts of a person's time, and in which he acts not as a particular personality rewarded according to his personal merit and

42. "Too many educated people," friends often said, "can only mess things up in a village." They contrasted the smooth cooperation that prevailed in the hamlet to the sorry state of affairs in the village on the main road. "Too many pegawai (white-collar workers) carrying on like experts," was how one friend put it. "It's better for only a couple of people in a village to have ideas. Dumb guys work harder."

One remarkable aspect of sekaa organization is that people charged with financial responsibilities are trusted implicitly. But this trust in money matters does not extend beyond the village, and often no farther than the hamlet. Officials and businessmen in town are considered no more honest than their counterparts in Java. Much, in fact, of Balinese social cohesion no doubt depends on the relatively slight degree of urbanization, a situation which has only recently begun to alter significantly. 
performance, but more as one among many different but "categorically" equivalent units. I am not of course referring to the feelings Balinese have about what they do, but about the way in which responsibilities are enforced and rewards distributed. One is tempted to say that the Balinese, unlike the Javanese, have a notion of "the public," of public responsibilities. Indeed, the Western idea of the public takes the notion of individuals as units in combining categories to its fullest expression. But the Balinese have no such abstract notion of society, and submit to no such impersonal authorities as Western institutions. Balinese groups never attain the impersonal generality, nor do they differentiate and gradate individuals like many Western organizations. Instead, they combine people in interlocking sets while neither implicating nor abstracting their persons. 43

Individuals in Bali join any number of groups and yet never compromise the particular notion of 1 imits that characterizes their interaction. There is form, authority, fiber outside the binary set of I and you. But then again, these are hardly concentrated in a single individual, group or institution. I think it is a result of this diffuse but real form in Balinese society that two people can act with somewhat greater freedom of movement there than in Java. The difference is only one of degree, but their expression does not include so many marked signs for status and relative familiarity. I suspect that such signs are less important because such considerations are not the only ways that two people can be 1 inked to each other. Among strangers, such markers are relatively important. But in the thick of a sekaa, even a measure of real stress can be placed on the otherwise delicately protected bonds between people. Except in town, the twine rarely snaps, even if the friendship wears. The Balinese divide and group themselves in endless numbers of ways, from the organs within their bodies, to the numerous organizations in village life, to caste, and yet always come out, in fact remain at all times, whole.

Two Images of Balinese Interaction: Arja and Gamelan

In such a successful operation as Balinese sekaa, it seems more appropriate to speak of examples than ideals for action. I have given several examples above, but there is one example of Balinese interaction that beautifully sums up the way the Balinese can apply form to the particular and come out both ahead and untouched. Arja--one of Bali's many performing arts--begins with the appearance of the condong, a maidservant who dances, sings and speaks, extolling her mistress's virtues and indicating the problem that will be the focus of the plot. Then Galuh, the beautiful heroine, joins the condong on stage. She is invariably troubled about something and her maidservant tries to console her. Following their exit, Limur, a mother figure, performs, singing and dancing in alternation with spoken monologues. She usually has designs of an evil nature. She is joined onstage by her child and/or Désak, a female attendant. Then Panasar, a male servant appears.

43. I do not think this pattern indicates a denial or disvaluation of personhood, of personal identity. It is simply a refusal to differentiate according to such considerations in a situation predicated on equality. Nor do I think birth-order names (see Geertz, "Person, Time and Conduct") need to be taken as indicative of such an attitude. I would say that they stress that a person is a member of a group, a group of $k$ in, just as his birth is not his alone, but of five brothers: the baby plus the fluids, placenta and afterbirth that accompany him. 
He sinks in a booming voice and struts about grandly. He summons his younger brother, I Ketut Kartala, and together they go through a clowning routine. The panasar tends toward bombast, kartala to sarcastic wit beneath a foolish exterior. By this time it is usually twelve or one at night, the performance having begun at nine or ten. The plot has advanced very little. Only after the clowning by the panasar and kartala does the plot get underway, and the form becomes less predictable. However, there should be a good tear-jerking scene with the hero, who appears after the male clowns, and/or heroine. Often a mantri (prince or minister) appears around three, along with a second set of panasar and kartala. The performance ends by five or six in the morning.

The form as outlined above is not invariable beyond the first three scenes, although the cast of characters is close to set. The point is that widely divergent plots get fitted onto this set of characters and scenes. Folk stories, wayang plots and literary morality plays all get adapted to, and considerably distorted by the form. Often whatever internal dramatic mechanic the story may have had dissolves completely in the face of arja's resolute pattern. So in the lontar version of Gagakturas, the text focuses on a man's passage to heaven to reclaim his bride, while in the arja version I saw, that section took up only a few minutes between the melodramatic cemetery scene and the slapstick (!) scene in heaven. What is more, the Balinese have distinct notions about the character of each arja figure. So no matter whether Galuh is Sinta in the Ramayana or a more modern princess, she is at all times-Galuh. The same applies to all the characters. They can take on any number of identities and yet they are always themselves. On the other hand, one performance usually has two panasar and two kartala, who dress identically and for the most part act alike. They differ only in that they serve different princes. So different people can take on what is practically a single role, while single identities are hardly affected by any role they take on. It is a tell. ing image for a society in which any one person can take on any number of roles in numerous kinds of sets and yet never be constrained significantly to shape the way he acts for the roles he takes on. He can work in many different sekaa, and yet never compromise his status (no matter what his caste), see any infringements on his rights, or feel his person in any way implicated beyond following a few uniformly applied rules.

If arja shows the buoyancy of individuals, Balinese gamelan illustrates their ability to work in stunningly disciplined sets. Balinese gamelan is more accessible to Western ears than Javanese gamelan. Its sound is more brilliant and its rhythms much more immediately remarkable. (Lovers of Javanese gamelan tend to find Balinese music unsubtle; people partial to Balinese music think Javanese music soporific.) Certainly gamelan is a more living tradition in Bali, where many more villages have excellent ensembles and there is constant invention of new gending. In fact, since the beginning of this century, Balinese gamelan has undergone many modifications. In what follows, I will briefly describe the modern gong kebyar, the most common type of ensemble in Bali today. ${ }^{4}$

Gong kebyar can be divided into sets, a11 of whose members must interact very precisely. One set, the jègogan, jublag, calung and

44. Gong kebyar is only one of several distinct musical ensembles in Bali, each with its own scale and use. Colin McPhee's Music in Bali (New Haven: Yale University Press, 1966) gives a thorough account of all these musical forms. 
various gangsa, all resemble the Javanese slentem in that they consist of bronze bars suspended over bamboo resonators and are played with one hand striking, the other damping, the keys. The principle that instruments with a higher range are struck more frequently than ones with lower ranges applies here just as it does in Java. The calung, with five bars, plays something similar to the balungan in Javanese music, called the giing gending (literally, the spine of the gending). This giing is marked off at certain intervals by the much larger jublag or jègogan, also with five bars, as well as the several gongs. (in order of increasing frequency): gong, kempur, kentong (al1 hanging gongs) and the kempli (a standing gong). Actually, many ensembles dispense with the calung altogether. That leaves the various gangsa. All gangsa have ten, eleven or twelve bars, depending on the particular gamelan. The largest are the two gangsa giing, or gangsa jongkok, one placed in front of the other. They play fairly close to the giing gending but with many variations added at the discretion of the player. "The player in front, the juru embat, leads all the players. His gestures indicate the instant at which all players must begin a section or phrase, when to play softly or loudly, and when to speed up (the latter in cooperation with the drummers). In rehearsal especially, he looks around to glare at, coach or laugh with the other players as they go through a piece. He has the greatest freedom to improvise variations to the giing gending, but he must land on the principal note at least every fourth beat. The smaller gangsa are called pemadé and kantiz. They play at higher ranges and form linked pairs of interlocking ornamentation to the giing. The principle resembles the imbal pattern in Javanese gamelan but here expanded and varied in several different, extremely speedy and tricky patterns. The variations often include sudden shifts in rhythm that must be practiced tirelessly until they become fully automatic. The basic idea usually involves four consecutive notes of which the first and fourth are played simultaneously and the second and third in alternation. The players in front, at either side of the juru embat, take the main part of the ornamentation (the one ending on the main note) while the players behind them take the second part, called $n /$ timpalin (to accompany, from timpal = friend). Which pattern of ornamentation is to be used for any particular section must be established by the players, and so there is almost no room for individual variation.

The role of the juru embat is eclipsed whenever a terompong is used. The terompong, star of the older gong gedé, is now used only in temples or at times requiring classical playing: It resembles the Javanese bonang but its ten gongs are arranged in a single row, and play to a deeper range. Jurisdiction over introducing gending, shifting from one section to the next and indicating tempi and volume, otherwise given over to the juru embat, all lie with the terompong player when he is present. A great terompong player is the outstanding member of an ensemble and it is a shame that the terompong is now used more and more rarely. Similar to the terompong is the réyong, also a row of gongs but thirteen in number and played by four musicians rather than one. They play ornamentation similar in principle to that of the smaller gangsa, in two sets of interlocking parts. Their timing must also be precise to the split second. One of the four gives cues which the other players follow. Played we11, the réyong produces a singularly beautiful sound that seems to come forward on the wind in crescendo and then passes on by. Its technique, involving sudden shifts in territory (which gongs are struck by which player) is the most difficult aside from druming.

The result of the different types of ornamentation the gangsa and réyong play is a sort of highly controlled dissonance in a jazzy kalei- 
doscope of bright, hard sounds. The overall effect might be 1 ikened to a highly embellished silver tray, an intricately worked surface that is busy, beautiful and quite flat. Any remaining "space" is filled with the sound of the flute--playing the main melody--and the cencèng, small but quite ferocious cymbals.

If the techniques of the smaller gangsa and réyong are remarkable, the technique of modern druming in Bali is mind-boggling. Only the Balinese could create anything so intricate, and in a way gratuitously difficult, as giving the drumming over to two players who must coordinate their efforts in split-second precision at unimaginable velocity. True, one drum, the "male," has a certain dominance in setting tempo and the amount of ornamentation played to the basic beat. The "female" drum (slightly larger), on the other hand, has primacy in certain shifts in section, like signaling the termination of a gending. To complicate matters further, the drums are struck sometimes with the hand (as in Java), sometimes with a panggul, a round-headed stick (the traditional method of gong gedé) in the course of a single gending. In villages, the thudding sound that results can be heard for miles.

Most Balinese gending are, like Javanese ones, basically circular, in that major sections can theoretically be played over an unlimited number of times. In practice, however, no section is usually played more than twice, and many long transitional sections cannot be repeated. In modern gending, classical form has given way to free form, requiring memorization not just of the giing but of each part individually. Old patterns are taken over, but, for example, the gong is struck much more frequently, there are more sudden shifts in volume and the overall effect is much flashier. 45

These dramatic flourishes require giving much more precise cues than is possible in Javanese gamelan. As in Java, it is the drum beat that holds everyone in place. But especially in modern compositions, the sudden starts, stops and dynamics of volume and stress require precise cues which only the juru embat can give. Only he can indicate the instant at which the gangsa players must start a phrase. The réyong players must also observe his cues. For this reason, players in performance are usually arranged in two groups facing each other, at either side of the stage. The juru embat sits on a raised stool and lifts his mallet high, in a quite theatrical gesture, whenever his guidance is needed. At other times, he indicates certain shifts in sections of the gending. Clear authority is in effect exercised by a single player in Bainese gong kebyar over areas that in Javanese gamelan cannot be so precisely controlled: sudden shifts in volume, solo parts, and tempi. Generally speaking, Balinese gending are much more strictly set than Javanese: the intricately interlocking ornamental parts played by the réyong and gangsa leave little room for the free variation that is essential to Javanese playing.

A striking feature of Balinese music, and a major reason it is so much more accessible to Western ears, is the presence of a readily discernible line. One can always pick out a particular direction, some-

45. Often these modern compositions are also quite formless. In tari lepas, the popular dance form based on the classical legong kraton, the music is awful: virtuoso playing, but shapeless and without grace, used to accompany dance of equally empty display. The shift from a classical story told in stylized gesture to the crudely representational dance fragments like tari tenun (Indonesian, weaver's dance) is regrettable. 
times almost a single voice in Balinese music, even though it is greatly embel1ished. Yet the line cannot be isolated on one instrument, because, in fact, it is not a single voice at all, but many voices very strictly interwoven. The unity of sounds stems from the relative lack of aural contrast, the absence of any vocal part, the use of a limited harmony between instruments and extremely close rhythmic and tonal interaction. Balinese music pieces sounds together mosaic-1ike, with each piece distinct but fitting into the cluster of each group within the ensemble: the gangsa, calung, jublag and jègogan; the réyong; the gongs; and the drums and cèncèng. These sections, like fields of a single color in a mosaic--or the degrees of generality that 1 ink together increasingly large and cross-cutting groups in Balinese villages-combine to form an overall design of remarkable unity and clarity. What holds the whole design together is not a single authority, but an authority splintered among several players. The drummers, terompong player and/or gangsa giing player and lead réyong player seem to me to cooperate much more closely than their counterparts in Javanese gamelan. And the musical unity lies not in the congruent range of tones (paţet) and nodal points that link discrete lines in Javanese gamelan, but the formation of a tighter musical line by the strictly coordinated playing of instruments no one of whom plays a complete melodic line. Like Balinese working together in any sekaa, common compliance to "authority" is possible, but that authority lies dispersed among many individuals, and applies only to particular spheres. The unity and total effect depend on the interaction--momentary, singlepurposed, precise--of the constituent members. In work organizations, this pattern yields vigorous, flexible and quite remarkably smooth interaction. In music, it yields the electric, mercurial and dazzling sounds of gong kebyar.

Summing up makes one state baldly what one would prefer to leave a little vague. But to clarify the ways that I think Javanese and Balinese interaction--musical and social--can be related to each other, I will try to draw a few bolder 1 ines.

Javanese and Balinese gamelan show evident similarities in the way that instruments are combined around a basic line marked off at given intervals by various gongs. Both are organized on the principle of the higher an instrument's range, the more frequently it is struck, giving the instruments a kind of geometric relationship. The variations and differing frequencies keep the instruments playing as though on different planes, all parallel to the balungan or giing. And in both Java and $\mathrm{Bali}$, notions about interaction--while providing considerable range in expression--still assume certain limits which are not to be transgressed. In Javanese music, the contrasting textures and variations keep the players resolutely distinct. In Bali, the contrasts are much less distinct, but the players combine in much more vigorous rhythmic and to a limited degree even harmonic interaction, in very intricate, strictly controlled ornamentation. And the greatest single contrast between Javanese and Balinese village life, in fact, lies in the greater capacity of the Balinese to form viable groups. Those groups are arranged in a way consistent with the Balinese tendency to divide and redivide the world into cross-cutting sets. Their operation is consistent as well with Balinese notions of the limits to interaction. The Balinese do not lay such stress on the fine expression of one to one encounter as the Javanese, and their music lacks Java's breathtakingly delicate nuances. But they succeed in combining individual efforts in energetic group action, whether village labor or village gong, without compromising anyone's sense of his own sovereignty. 
It is Claude Lévi-Strauss's great gift to anthropology that we are released from the need to explain one aspect of culture in terms of another, privileged source of meaning. Levels of culture refer to each other, not to a single point. I do not think the musical traditions of Central Java and Bali can be explained in terms of their social structures. Instead musical patterns and social patterns in the two areas resemble each other much as their languages reflect, repeat, hint at or contradict each other. I wrote this paper to try to figure out why the experience of living in Bali and Java felt like hearing a single melody in different keys. To do so, I have isolated little themes, in language, etiquette, face to face encounter and group action, themes whose summation sounds particularly clearly in the two cultures' musical expressions. But in the end, I can only admit that each of these two cultures, like their respective musics, is a presence as integral, indefinable and enveloping as the deep, soft tones of a final gong. 